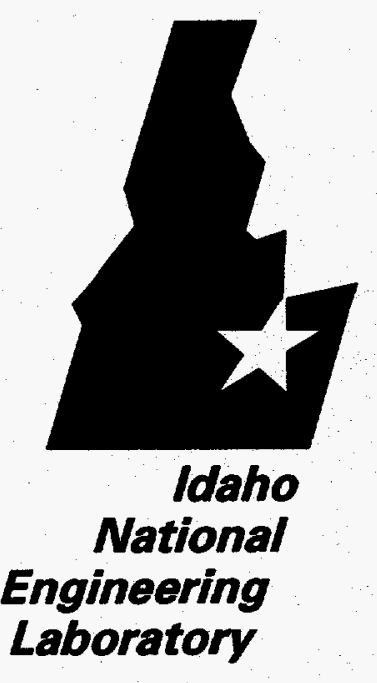

Engineering
Idaho Chemical Processing Plant Process Efficiency Improvements

\author{
RECENED \\ MAY 22 1996 \\ OSTI
}

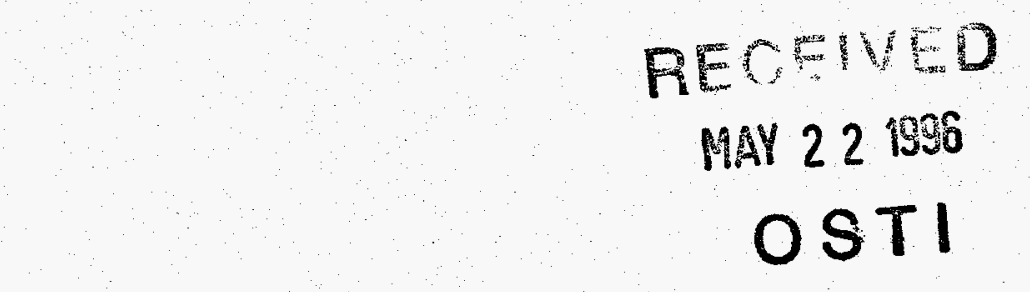

Brad Griebenow

March 1996 


\section{DECLAMMTR}

Portions of this document may be illegible in electronic image products. Images are produced from the best available original document. 


\section{Idaho Chemical Processing Plant Process Efficiency Improvements}




\title{
Idaho Chemical Processing Plant Process Efficiency Improvements
}

\author{
Brad Griebenow
}

Published March 1996

\begin{abstract}
Idaho National Engineering Laboratory Lockheed Idaho Technologies Company Idaho Falls, Idaho $\mathbf{8 3 4 1 5}$
\end{abstract}

Prepared for the

U.S. Department of Energy

Assistant Secretary for Environmental Management Under DOE Idaho Operations Office

Contract DE-AC07-94ID13223 


\begin{abstract}
In response to decreasing funding levels available to support activities at the Idaho Chemical Processing Plant (ICPP) and a desire to be cost competitive, the Department of Energy Idaho Operations Office (DOE-ID) and Lockheed Idaho Technologies Company have increased their emphasis on cost-saving measures. The ICPP Effectiveness Improvement Initiative involves many activities to improve cost effectiveness and competitiveness. This report documents the methodology and results of one of those cost cutting measures, the Process Efficiency Improvement Activity.

The Process Efficiency Improvement Activity performed a systematic review of major work processes at the ICPP to increase productivity and to identify nonvalue-added requirements. A two-phase approach was selected for the activity to allow for near-term implementation of relatively easy process modifications in the first phase while obtaining long-term continuous improvement in the second phase and beyond. Phase I of the initiative included a concentrated review of processes that had a high potential for cost savings with the intent of realizing savings in Fiscal Year 1996 (FY-96.) Phase II consists of implementing long-term strategies too complex for Phase I implementation and evaluation of processes not targeted for Phase I review. The Phase II effort is targeted for realizing cost savings in FY-97 and beyond.
\end{abstract}

\title{
DISCLAIMER
}

This report was prepared as an account of work sponsored by an agency of the United States Government. Neither the United States Government nor any agency thereof, nor any of their employees, makes any warranty, express or implied, or assumes any legal liability or responsibility for the accuracy, completeness, or usefulness of any information, apparatus, product, or process disclosed, or represents that its use would not infringe privately owned rights. Reference herein to any specific commercial product, process, or service by trade name, trademark, manufacturer, or otherwise does not necessarily constitute or imply its endorsement, recommendation, or favoring by the United States Government or any agency thereof. The views and opinions of authors expressed herein do not necessarily state or reflect those of the United States Government or any agency thereof. 


\section{EXECUTIVE SUMMARY}

In response to decreasing funding levels available to support activities at the Idaho Chemical Processing Plant (ICPP) and a desire to be cost competitive, the U.S. Department of Energy Idaho Operations Office (DOE-ID) and Lockheed Idaho Technologies Company have increased their emphasis on costsaving measures. As shown in the tabulation to the right, the ICPP Effectiveness Improvement Initiative involves many activities to improve cost effectiveness and competitiveness. This report documents the methodology and results of one of those cost-cutting measures, the Process Efficiency Improvement Activity.

ICPP Effectiveness Improvement Initiative.

- Budget allocation reduction

- Process efficiency improvement activity (Phase I)

- HLW work package budget review

- SNF work package budget review

- Infrastructure work package budget review

- Rover turnback

- Electrical upgrade project reductions

- Process efficiency improvement activity (Phase II)

- Additional future activities

During the last quarter of Fiscal Year 1995 (FY-95), a cost evaluation team consisting of members from DOE-ID and Lockheed Idaho conducted a joint evaluation of nine ICPP work processes and associated costs at ICPP. The team identified the steps associated with completing the work processes, assigned costs to complete the steps, and identified the "low value" steps that, if eliminated, would generate cost savings without adversely affecting the product. The conclusion of the evaluation, as documented in the "Wichmann Report," was that about $13 \%$ of the steps associated with these nine processes did not add value. The study also determined that the vast majority of the nonvalue-added activities were required by current orders, procedures, and regulations; and "the total reinvestment [based on resource allocation] will not be realized for at least 2 years from initial re-engineering." One of the recommendations in the Wichmann Report was to "initiate a systematic review of major work processes at the Idaho Chemical Processing Plant using activity-based management techniques to increase productivity and to identify nonvalue-added requirements." The Process Efficiency Improvement Activity was started to fulfill this recommendation and to realize some of the cost-saving potential identified in the report.

A two-phase approach was selected for the activity to allow for near-term implementation of relatively easy process modifications in the first phase while obtaining long-term continuous improvement in the second phase and beyond. Phase I of the initiative included a concentrated review of processes that had a high potential for cost savings with the intent of realizing savings in FY-96. Phase II consists of implementing long-term strategies too complex for Phase I implementation and evaluation of processes not targeted for Phase I review. The Phase II effort is targeted for realizing cost savings in FY-97 and beyond.

To kick off Phase I of the initiative, a steering team of DOE-ID and Lockheed Idaho managers reviewed the 11 product lines supported at ICPP and rated each product line based on the perceived potential for cost savings. To keep the initiative manageable, the seven highest-rated functional areas were selected for detailed review during Phase I. Teams were established to review the processes involved in each of the functional areas. In instances where a functional area was too large for review by a single team, the area was subdivided and reviewed by additional teams. Ultimately, 11 improvement teams consisting of approximately $100 \mathrm{DOE}-\mathrm{D}$ and Lockheed Idaho employees were established to review work processes in the functional areas. Based on the two-phase approach, the teams were requested to identify (a) Phase I process improvement recommendations that would result in near-term savings (those that could be realized during the 
second quarter of FY-96) and (b) Phase II recommendations not suitable for immediate implementation but with potential for cost savings during outyear budgets.

By the end of Phase I, the teams had identified 125 recommendations for process improvements. The steering team reviewed the recommendations and, during a 2-day facilitated session, evaluated each. Recommendations were evaluated based on their feasibility for implementation, elimination of nonvalue-added activities, and potential for cost savings. The steering team rejected seven recommendations, based on regulatory, safety, or implementation concerns. The remaining recommendations were reviewed to combine related recommendations and to broaden recommendations that could be applied to other areas of the plant. The steering team then determined whether the recommendations could be implemented in Phase I or had to be further investigated prior to implementation in Phase $\Pi$. Forty-six recommendations were approved for Phase I implementation. An additional 29 recommendations were identified for implementation during Phase II.

For each of the Phase I recommendations, cost savings were estimated and the control accounts used to fund the improved activity were identified. Rough-order-of-magnitude cost-saving estimates were also established for the recommendations identified for Phase II and will be refined as Phase II of the initiative continues. As shown in Table 1, the first phase of the Process Efficiency Improvement Activity has identified more than $\$ 17 \mathrm{M}$ in estimated annual cost savings subsequent to implementation of the Phase I and Phase II recommendations.
Table 1. ICPP Effectiveness Improvement Initiative estimated cost savings.

\begin{tabular}{||l|r|r||}
\hline \multicolumn{1}{|c|}{ Title } & Annual Savings & FY-96 Savings \\
\hline Improvement Team (Phase I) & $\mathbf{\$ 4 , 4 3 4 , 9 0 0}$ & $\mathbf{\$ 1 , 8 6 2 , 6 3 2}$ \\
\hline Paperwork/Review Reduction & $\$ 837,100$ & $\$ 543,210$ \\
\hline Monitoring & $\$ 1,135,500$ & $\$ 485,700$ \\
\hline Spent Fuel Operations & $\$ 570,800$ & $\$ 50,400$ \\
\hline High Level Waste Operations & $\$ 458,600$ & $\$ 95,100$ \\
\hline Plant Operations (General) & $\$ 210,400$ & $\$ 89,930$ \\
\hline Balance of Plant & $\$ 1,222,500$ & $\$ 598,292$ \\
\hline Phase II & $\mathbf{\$ 1 2 , 8 0 0 , 0 0 0}$ & $\mathbf{\$ 0}$ \\
\hline TOTAL & $\sim \mathbf{\$ 1 7 , 2 0 0 , 0 0 0}$ & $\mathbf{\$ 1 , 8 6 2 , 6 3 2}$ \\
\hline
\end{tabular}




\section{ACKNOWLEDGMENTS}

Phase I of the Process Efficiency Improvement Activity required the support of a large number of people. The commitment of those involved in this activity, from steering team members to improvement team members, ensured the activity's successful completion. Team member participation is greatly appreciated. Team members are as follows:

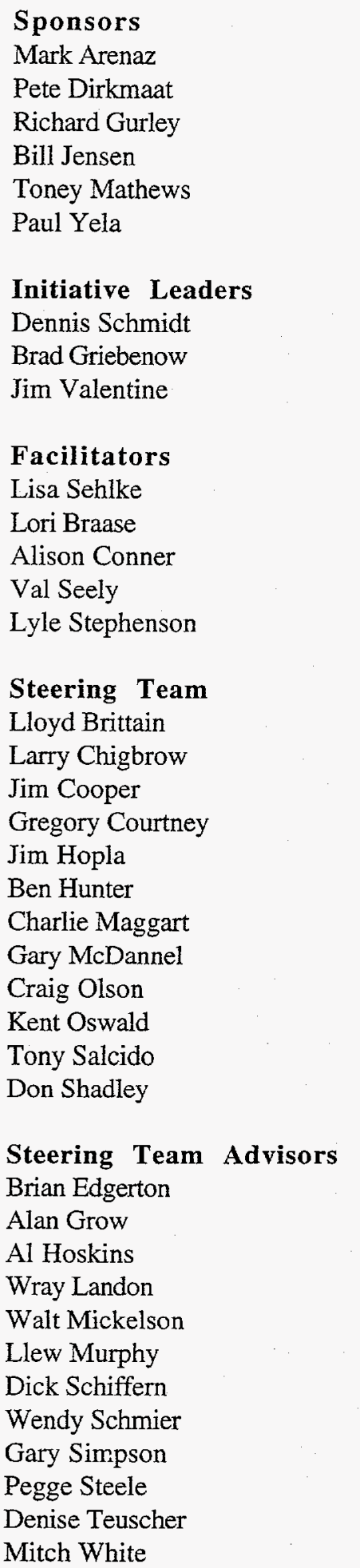

\author{
Maintenance/Work \\ Control \\ Bill Chatterly, champion \\ Mike Duffy, team leader \\ Allen Jorgensen, team leader \\ Michelle Barr \\ Brad Briggs \\ Jason Chapple \\ Don Garbe \\ Kent Hansen \\ David Hantman \\ John Howard \\ Engineering Support \\ Gary McDannel, champion \\ Loral Decker, team leader \\ Lee Bendixsen, team leader \\ Kenny Custer \\ Kurt Fielding \\ JD Tolman
}

Spent Fuel Operations

Mitch White, champion

Randy Vaden, team leader

Ed Armstrong

Bryan Crofts

Al Fullmer

John Hansen

Jordan King

Eric Mickelsen

Mike Myler

Bob Norris

\section{ES \& H}

Craig Olson, champion

\section{RadCon Team}

Frank Hinkley, team leader

Steve Aitken

Dave Diaz

Bob Mozes

Lex Strain

Alan Wood
ES\&H (Cont.)

Industrial Hygiene Team

Ron Bone, team leader

Tom Byrnes

Jim Downes

Kim Steed

Julie Waddell

High Level Waste

Jim Hopla, champion

Calcination Team

Kip Winter, team leader

Doug Archibald

Griff Colson

Angela Dismuke

Keith Fry

Mike Greene

Dave Heasley

Mike Ison

Dennis Norwood

Dan Palmer

Waste Processing Team

Earl McMahen, team leader

Kevin Barton

Bob Davis

Dick Frasure

Ron Hastings

Steve Martin

Blake Maxfield

Joe Parrette

Brady Talbot

Frank Ward

\section{Separations Team}

Ron Woodworth, team leader

John Arrowood

Jim Barker

Julie Merrill

Dave Olsen

Charles Posegate
Infrastructure

Russ Stuart, champion

Utilities Team

Brian Gustaveson, team leader

Wade Anderson

Dave Diaz

Charlie Fromer

Leon Pruett

Dave Suhre

Bill Verlanic

\section{Landlord Team}

Jack Simonds, team leader

Lloyd Brittain

Thayne Lords

Heavy MacFarlane

Bob Marcinko

Don Wood

Quality Assurance

Alan Grow, champion

Mike Wilberg, team leader

Mary Baker

Larry Davis

Sandra Drussel

Gary Keith

Dave Peterson

Tony Salcido 


\section{CONTENTS}

ABSTRACT $\ldots \ldots \ldots \ldots \ldots \ldots \ldots \ldots \ldots \ldots \ldots \ldots \ldots \ldots \ldots \ldots \ldots$ iii

EXECUTIVE SUMMARY $\ldots \ldots \ldots \ldots \ldots \ldots \ldots \ldots \ldots \ldots \ldots \ldots$ iv

ACKNOWLEDGMENTS $\ldots \ldots \ldots \ldots \ldots \ldots \ldots \ldots \ldots \ldots \ldots \ldots$ vi

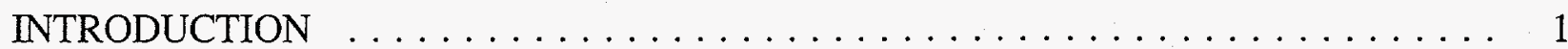

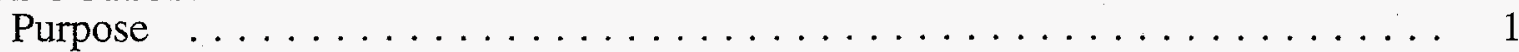

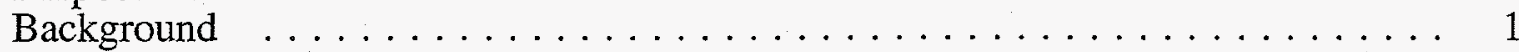

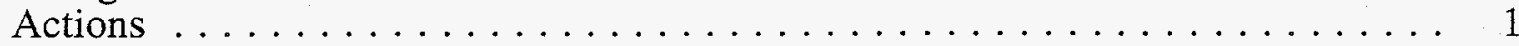

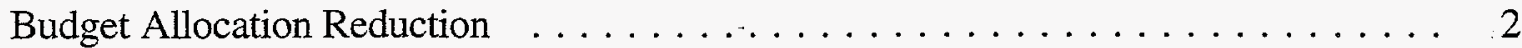

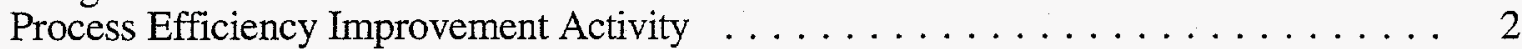

High Level Waste Work Package Budget Review $\ldots \ldots \ldots \ldots \ldots$

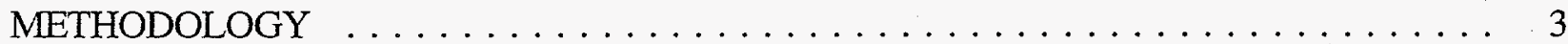

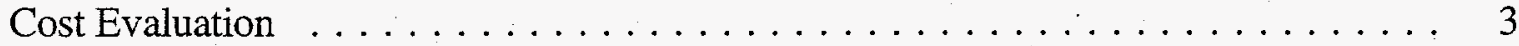

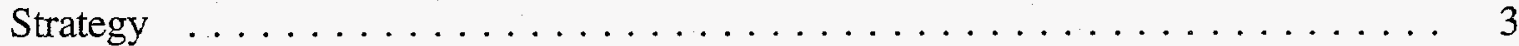

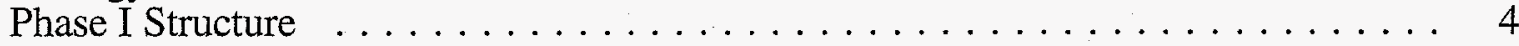

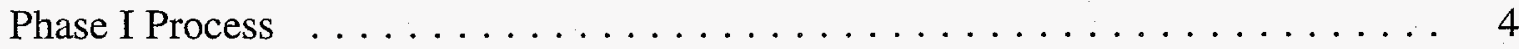

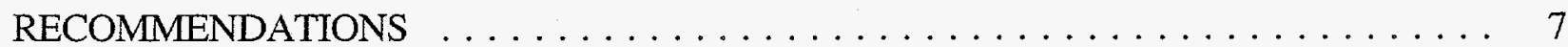

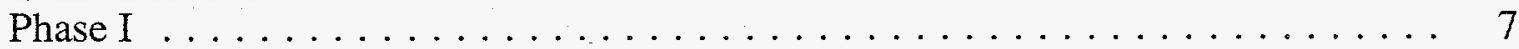

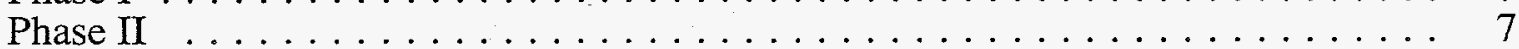

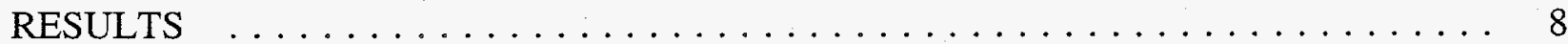

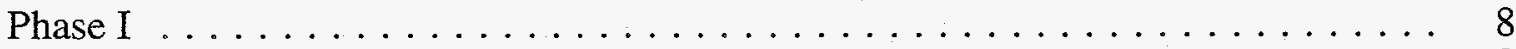

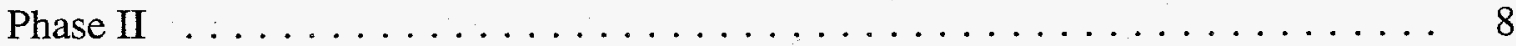

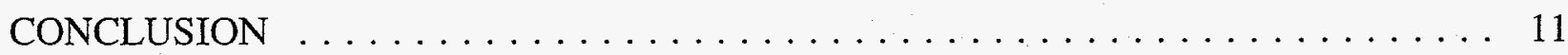




\section{INTRODUCTION}

\section{Purpose}

The Idaho Chemical Processing Plant (ICPP) is in the process of a multifaceted approach to reducing the cost of doing business. Some of the aspects of cost-saving activities are listed below:

- Budget allocation reduction

- $\quad$ Process efficiency improvement activity (Phase I)

- $\quad$ High Level Waste work package budget review

- Nuclear Fuel work package budget review

- Infrastructure work package budget review

- Rover turnback

- $\quad$ Electrical upgrade project reductions

- $\quad$ Process efficiency improvement activity (Phase II)

- $\quad$ Additional future activities.

These combined activities comprise the ICPP Effectiveness Improvement Initiative. Although this report focuses on the methodology and results of the Process Efficiency Improvement Activity, it is important to understand that the overall savings ultimately achieved in FY-96 will be a combination of savings from each of these efforts. To give the "big picture" of the ICPP Effectiveness Improvement Initiative, two additional aspects of the initiative, the budget allocation reduction and High Level Waste work package budget review, are briefly discussed below. The remainder of the report provides detailed information on the Process Efficiency Improvement Activity.

\section{Background}

The FY-96 budget submitted to Congress by the President included nearly $\$ 205.9 \mathrm{M}$ for the U.S. Department of Energy Idaho Operations Office (DOE-ID) to conduct stabilization and waste management activities at ICPP. As Congressional action on the FY-96 budget proceeded and FY95 drew to a close, it became apparent that the FY-96 budget for ICPP would be significantly lower than the requested amount, perhaps as much as $15 \%$. In response, DOE-ID and Lockheed Idaho Technologies Company elected to restrain the ICPP programs in FY-96 to reflect this anticipated funding reduction. Budget exercises based on the $85 \%$ funding case resulted in $\$ 30 \mathrm{M}$ worth of activities falling "below the line," leading to the desire to identify an equal amount of cost savings within the $85 \%$ of funded activities to bring the unfunded activities back "above the line."

The funding restrictions imposed by DOE-ID and Lockheed Idaho reduced the scope of some ongoing ICPP programs and delayed the start of others. Technology development projects needed to support ultimate disposal of highly radioactive liquid and solid waste and spent nuclear fuel were impacted the most. Delays in these programs would significantly impact DOE-ID and Lockheed Idaho's ability to meet the long-term commitments contained in the agreement just reached between DOE, the Navy, and the State of Idaho, referred to as the Batt Settlement Agreement. These impacts made it essential that DOE-D and Lockheed Idaho work together to determine if appropriate work was being methodically conducted, properly funded, and efficiently performed. 


\section{Actions}

Beginning in late FY-95, DOE-ID and Lockheed Idaho initiated an aggressive approach to streamline ICPP activities to attain higher levels of operating effectiveness and efficiency. Streamlining was intended to reduce the cost of completing the funded work and, thereby, generate funding for other workscope. The effort was viewed as a critical part of DOE-ID and Lockheed Idaho's plan for timely completion of ICPP mission objectives within the anticipated funding levels. The multifaceted approach to streamlining included steps to ensure full funding of activities critical to the completion of the Batt Settlement Agreement. An effort was completed to develop work packages that met the budget allocation reduction. The Process Efficiency Improvement Activity included systematic work process reviews to identify inefficiencies and recommend improvements. A High Level Waste work package budget review was performed to ensure appropriate funding was allocated in the cost accounts to support priority work.

\section{Budget Allocation Reduction}

In late FY-95, work packages were developed to baseline FY-96 ICPP activities. These work packages were built around the assumption that the full $\$ 205.9 \mathrm{M}$ budget request would be obtained by DOE-ID. The budget finally appropriated, however, was approximately $\$ 191.4 \mathrm{M}$. To support this budget reduction, Lockheed Idaho reviewed work packages and eliminated low priority work scope. In many instances, this review identified activities not necessary to fulfill the ICPP mission and their elimination resulted in more effective operations. Unfortunately, the reduction also included work scope considered critical to meeting the Batt Settlement Agreement. The critical work scope eliminated was targeted for reinstatement as additional funds were made available through cost-saving measures.

\section{Process Efficiency Improvement Activity}

In early FY-96, the Process Efficiency Improvement Activity was started using a structured review method patterned after the ICPP Cost Evaluation completed in September 1995. The activity focused on identifying process inefficiencies and recommending improvements. The goal was to identify measures that would streamline work processes at ICPP and allow FY-96 work scope to be accomplished with fewer resources than originally planned. Senior DOE-ID and Lockheed Idaho managers jointly sponsored the initiative led by a steering team of ICPP managers. The primary purpose of this report is to document the methodology and results of this initiative.

\section{High Level Waste Work Package Budget Review}

As a result of the December 1995 baselining effort to support the reduced budget allocation, the revised work packages documented work scope considered paramount to fulfilling the ICPP mission. A budget review was then performed to ensure that the level of funding associated with the work scope was appropriate and reflected the degree of priority for each activity. Budget modifications were completed to reflect changes resulting from reevaluation of required resources, cost variances from the first 4 months of the year already lapsed, and areas with identified potential for cost underruns. The necessity to free up funds to be reallocated to the currently unfunded Batt Settlement Agreement activities drove decisions to eliminate procurements, vehicles, and travel, not critical to meeting the ICPP mission. 


\section{METHODOLOGY}

\section{Cost Evaluation}

To understand costs associated with activities at the ICPP, a joint DOE-ID/Lockheed Idaho evaluation team, led by Tom Wichmann and Greg Frandsen, was formed in the last quarter of FY95. The team used activity-based management to simplify its evaluation process. The team prepared flow charts on nine ICPP business processes. The flow charts were used to develop resource diagrams identifying each step of the procedure, elapsed time, person hours and skills, and documents associated with the activity. Key information gathered by the team was a valueadded estimate of each activity and a link between the activity and its associated requirements. The review, as documented in the "Wichmann Report," concluded that $13 \%$ of activities performed were nonvalue-added. It also concluded that the vast majority of the nonvalue-added activities were required by current orders, procedures, and regulations. The potential for resource reallocation, based on elimination of the nonvalue-added activities, was expected to take at least 2 years to be fully realized.

The Wichmann evaluation team identified three major issues and formulated recommendations for each. The first recommendation was to clarify roles and responsibilities at both ICPP and DOE-ID. The second recommendation was to improve program control. The final recommendation was to "initiate a systematic review of major work processes at the Idaho Chemical Processing Plant using activity-based management techniques to increase productivity and to identify nonvalue-added requirements." Based on this recommendation, DOE-ID and Lockheed Idaho management developed the Process Efficiency Improvement Activity to review work processes with the intent of identifying cost savings that could be reallocated to unfunded activities.

\section{Strategy}

Recognizing the imminent nature of the budget concerns, as well as the need for long-term self-sustaining continuous improvement, the sponsors defined a two-phased approach (Figure 1.) Phase I of the activity included a concentrated review of processes with a high potential for near-term cost savings with the intent of realizing savings in early 1996. Phase II consists of the implementation of long-term recommendations, evaluation of processes not targeted for Phase I, and consideration of issues raised but not addressed during Phase I.

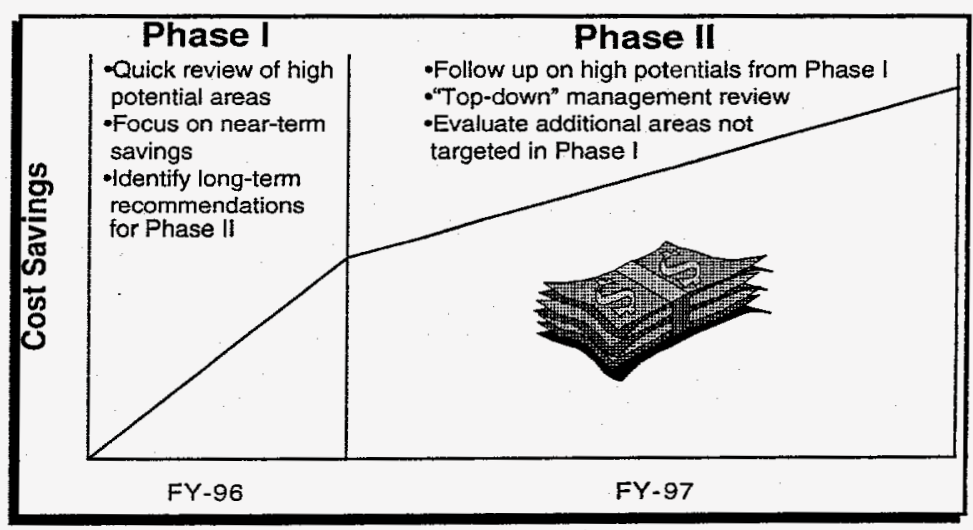

Figure 1 Two-phase approach 


\section{Phase I Structure}

The activity was structured to ensure appropriate involvement of individuals from different levels that represented different perspectives of work at the ICPP. Specific roles and expectations were defined for the steering team, champions, advisors, and improvement team members as shown in Figure 2.

Sponsors of the activity established a steering team of DOE-ID and Lockheed Idaho managers involved in much of the ICPP work. The steering team identified functional areas with high potential for improvement and cost savings, formed teams to appropriately evaluate the underlying processes, provided support and removed barriers for teams, and reviewed and approved recommendations.

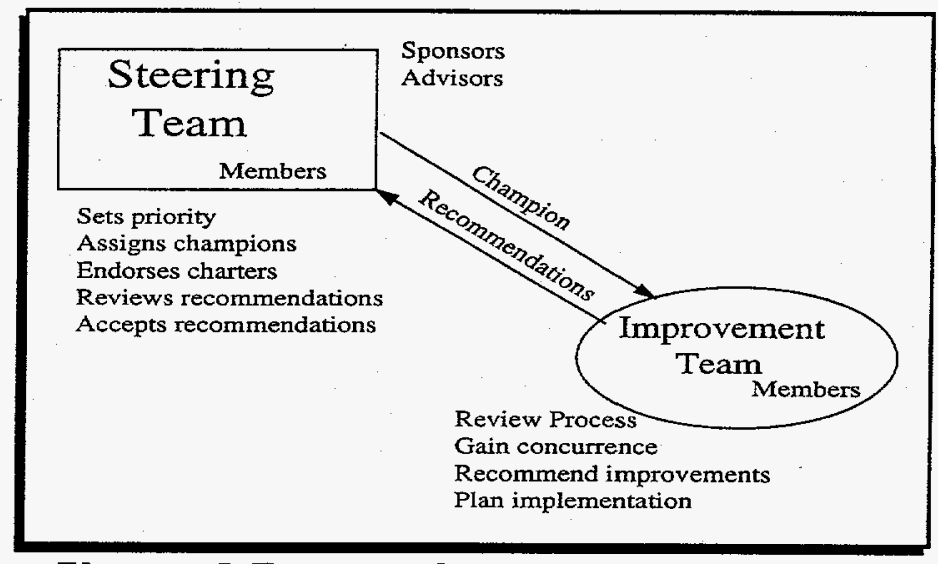

Figure 2 Team roles

The steering team appointed team champions for each of the functional areas identified for Phase I review. The team champion worked with a team of advisors (selected by the steering team) to target specific work processes in the functional areas. The targeted work processes were selected based on performance frequency, work complexity, process requirements, and allocated budget. Champions were also responsible for forming and mentoring process improvement teams to review targeted processes. Champions provided a link between the steering team and the improvement teams.

Improvement teams were formed to evaluate work processes. The teams of Lockheed Idaho and DOE-ID individuals, who were actively involved in the process to be evaluated, included process performers, customers, auditors, and suppliers. Facilitators were also part of the teams.

\section{Phase I Process}

During the activity kickoff meeting, the steering team evaluated the Lockheed Idaho work breakdown structure (including the associated control accounts) to identify the primary ICPP operations and cross-cutting services. These product and service areas contained a number of activity centers that became prime candidates for streamlining. In a session facilitated by Total Quality Management (TQM), the steering team reviewed the activity centers and prioritized the candidates based on perceived cost-improvement potential. The steering team considered such factors as:

- Total cost of the candidate activity

- $\quad$ Potential for saving a significant portion of the candidate's cost

- Repetitive nature of the work for which savings could be realized (i.e., one-time or multiple work activities)

- Perceived nonvalue-added content of the activity

- $\quad$ Complexity of the activity (i.e., amount of time required to perform the activity)

- Likelihood that appreciable savings could be achieved in the near term. 
Seven of the 11 product and service areas were selected for detailed review during Phase I. These seven areas included the three operation activity centers and four cross-cutting service centers. The steering team identified a management champion for each of the seven areas, ensuring that the champions did not have direct management responsibility for their assigned activity center. Champions were provided with a team of advisors knowledgeable about the work processes and funding for the respective functional areas. The champion and advisors further refined the focus of the process review by identifying specific processes that had high potential for improvement and cost savings.

Champions then formed process improvement teams of individuals directly involved in the work processes. Ultimately, 11 improvement teams, as shown in Figure 3, consisting of approximately $100 \mathrm{DOE}-$ ID and Lockheed Idaho employees were established to review work processes in the functional areas. The

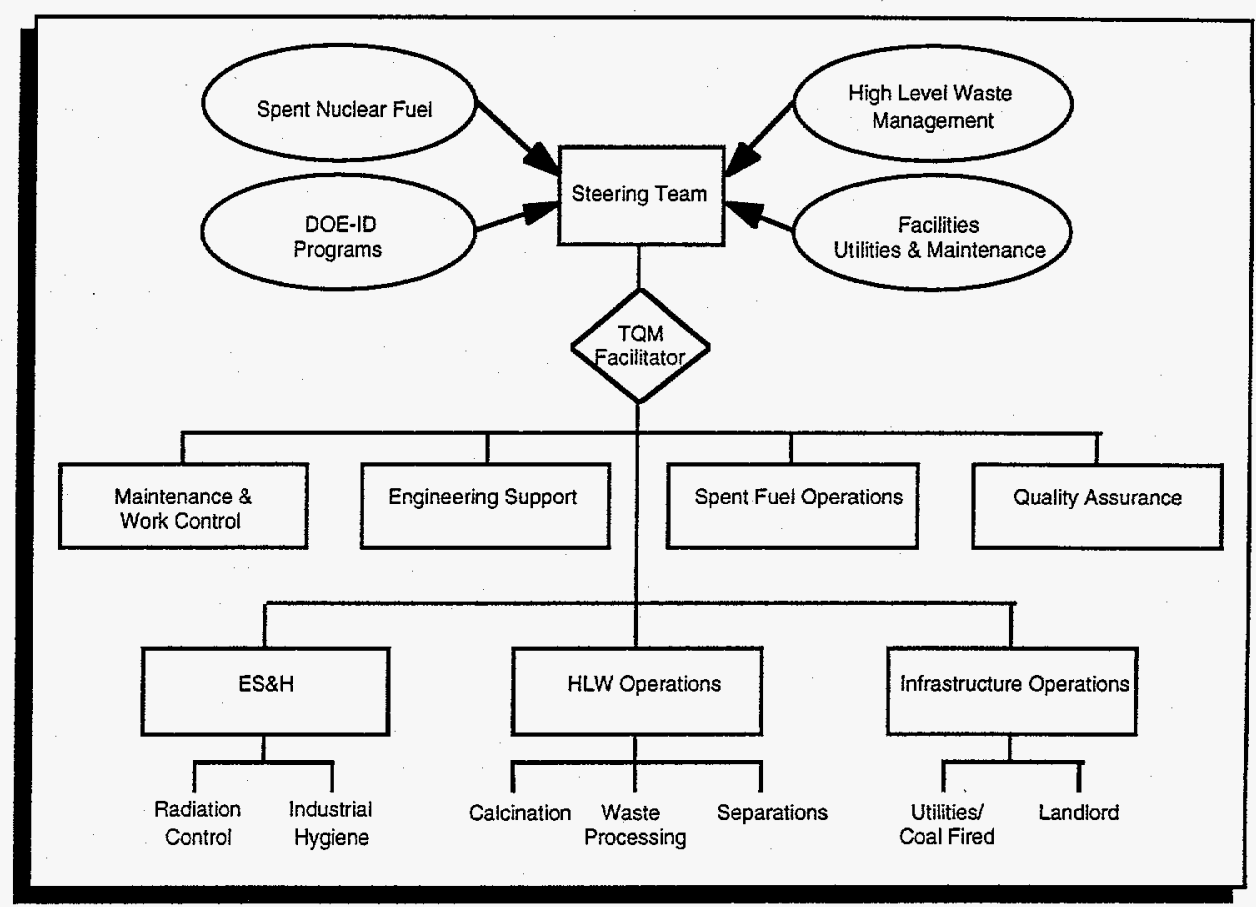

\section{Figure 3 Effectiveness improvement structure} teams were requested to define Phase I recommendations that would result in near-term savings and identify Phase II recommendations that might not be suitable for immediate implementation but that may have potential for cost savings in subsequent budget years.

Improvement teams evaluated work processes following a systematic process improvement model that included defining the existing process, evaluating the process, developing alternatives and making recommendations. Several TQM tools were used throughout teams' activities and included brainstorming techniques, flow charting, requirements analysis, priority setting, cycletime estimating, and benchmarking.

Defining the existing process was typically accomplished by developing a process flow chart. For each step in the process, teams identified the source of the associated requirements, the resources applied, and the expected outcomes or functional requirements. The teams focused a significant part of their reviews on understanding the requirements that drove the steps in the process.

Step two of the process compelled teams to critically evaluate each activity represented in the process flow chart to determine if the activity adds value, is performed efficiently, and contributes to the desired result. Particular emphasis was placed on challenging those requirements determined to add minimal value to the end product.

For each activity determined inefficient or nonvalue-added, the team proposed an alternative solution. In some cases activities were simply eliminated. In others, more efficient processes were developed. Teams tested their proposed solutions by interviewing knowledgeable personnel, 
benchmarking INEL and other organization approaches, and reviewing requirements.

Recommendations were formulated to represent proposed process improvements.

Recommendations were submitted to the steering team in written form and presented for evaluation by the team leader. Included in the recommendations was a description of the current process, the proposed change(s), justification for the change, advantages and disadvantages resulting from implementing the change, and estimated cost savings. Teams included data to support their cost estimates, identified issues associated with implementing the change, and suggested implementing actions and responsible individuals.

Steering team members reviewed each of the written recommendations to identify any questions or need for clarification. The steering team met in a 2-day facilitated session to listen to the team leaders present recommendations and to evaluate each recommendation. The steering team evaluated recommendations based on their ability to improve work at ICPP, save cost, and add value. 


\section{RECOMMENDATIONS}

The improvement teams submitted 125 recommendations to the steering team for approval. Of these, seven recommendations were eliminated due to regulatory, safety, or implementation concerns. The remaining recommendations were reviewed to identify related recommendations that could be combined as well as to identify recommendations that could be broadened to other. areas beyond the original improvement team's area. The steering team then determined whether the recommendations should be implemented in Phase I or Phase II, with a bias for action to move as many recommendations into Phase I as possible. The implementing actions associated with most recommendations could not be completed immediately, but aggressive schedules were developed for completing the actions and cost savings were calculated based on the scheduled implementation date.

\section{Phase I}

After combining related recommendations, 46 recommendations were approved for Phase I implementation. These recommendations were grouped into six categories: Paperwork/Review Reduction, Monitoring, Spent Fuel Operations, High Level Waste Operations, General Plant Operations, and Balance of Plant. Appendix A contains a brief description of the recommendations approved for Phase I implementation as well as the action items that must be completed to realize the identified cost savings. The identified cost savings were used to develop a change control package to allow reallocation of the funds to unfunded priority work.

\section{Phase II}

As a result of the Phase I improvement team actions, 29 recommendations were identified for implementation during Phase II and additional recommendations will be generated during Phase II. A Phase II action plan will be developed and initiated in the second quarter of FY-96. This action plan will consist of three basic elements:

1. A "top-down" senior management review to eliminate unnecessary ICPP work scope and extend the impact of the Phase I recommendations.

2. Implementation of "longer term" recommendations identified in Phase I and extension of some recommendations to additional ICPP processes.

3. Identification of recommendations in areas not previously investigated. 


\section{RESULTS}

\section{Phase I}

For each of the Phase I recommendations, the cost-saving estimate was tied to one or more control accounts that funded the improved activity. Typically, the estimated cost savings was calculated based on a full year of operation; therefore, to determine the FY-96 cost savings, the estimated total savings was reduced due to the fact that implementation would not occur until 5 or 6 months into the year. Additionally, the cost for implementing the recommendations, from activities such as changing procedures or technical specifications, was deducted from the total estimated savings to obtain the correct FY-96 cost savings amount. Table 2, on the following page, lists the Phase I recommendations and the associated annual and FY-96 cost savings. Appendix B provides a spreadsheet with the calculated annual cost savings, FY-96 cost savings, and associated control accounts.

\section{Phase II}

The Phase II recommendations are listed in Table 3, along with the estimated cost savings. The cost-saving estimates provided are rough-order-of-magnitude estimates, since the recommendations have not been fully investigated at this time. Phase II recommendations are targeted to result in cost savings in FY-97 and beyond. As previously stated, a Phase II action plan will be developed and initiated during the second quarter of FY-96. 
Table 2. Phase I recommendations and cost savings

\begin{tabular}{|c|c|c|}
\hline Title & Annual Savings & FY-96 Savings \\
\hline Phase I Total Cost Savings & $\$ 4,434,900$ & $\$ 1,862,632$ \\
\hline PAPERWORK/REVIEW REDUCTION (Subtotal) & $\$ 837,100$ & $\$ 543,210$ \\
\hline Increase Use of Job Safety Analyses & $\$ 135,000$ & $\$ 88,630$ \\
\hline Streamline Occurrence Reporting & $\$ 541,800$ & $\$ 353,200$ \\
\hline Eliminate Test Results Review Team & $\$ 36,000$ & $\$ 30,400$ \\
\hline Streamline Review of Plant Changes & $\$ 75,800$ & $\$ 40,300$ \\
\hline Improve Graded Approach of Quality Levels & $\$ 48,500$ & $\$ 30,680$ \\
\hline MONITORING (Subtotal) & $\$ 1,135,500$ & $\$ 485,700$ \\
\hline Reduce Bioassay Samples & $\$ 375,000$ & $\$ 200,000$ \\
\hline Reduce RadCon Techs Required for Moving Hot Dirt & $\$ 0$ & $\$ 27,600$ \\
\hline Reduce 603 Basin Water Sampling & $\$ 233,300$ & $\$ 115,000$ \\
\hline Reduce FAST Basin Water Monitoring & $\$ 103,600$ & $\$ 57,100$ \\
\hline Reduce FAST Stack Monitoring & $\$ 29,600$ & $\$ 29,600$ \\
\hline Improve Process for Obtaining Radiological Instrument Readings & $\$ 0$ & $\$ 0$ \\
\hline Modify RadCon Tech Utilization During Off-Shifts & $\$ 75,000$ & $\$ 0$ \\
\hline Reduce Main Stack Monitoring & $\$ 147,300$ & $\$ 0$ \\
\hline Reduce Tank Farm Monitoring & $\$ 99,000$ & $\$ 0$ \\
\hline Reduce Percolation Pond Checks & $\$ 14,400$ & $\$ 8,600$ \\
\hline Reduce Number of Sample Trip Blanks & $\$ 1,600$ & $\$ 1,100$ \\
\hline Obtain WCF Readings Remotely & $\$ 36,900$ & $\$ 23,900$ \\
\hline Reduce Deep Tank Monitoring & $\$ 19,800$ & $\$ 14,900$ \\
\hline Reduce Bulk Chemical Readings & $\$ 0$ & $\$ 7,900$ \\
\hline SPENT FUEL OPERATIONS (Subtotal) & $\$ 570,800$ & $\$ 50,400$ \\
\hline Reduce Fuel Charger Wrappings & $\$ 529,600$ & $\$ 10,000$ \\
\hline Modify Cask Water Filling Procedure & $\$ 0$ & $\$ 0$ \\
\hline Eliminate Unnecessary Cask Surveys & $\$ 35,000$ & $\$ 35,000$ \\
\hline Implement Lift Ring Stand & $\$ 1,200$ & $\$ 400$ \\
\hline Streamline Fuel Movement Plan Development & $\$ 5,000$ & $\$ 5,000$ \\
\hline HIGH LEVEL WASTE (HLW) OPERATIONS (Subtotal) & $\$ 458,600$ & $\$ 95,100$ \\
\hline Improve HLW Operator Utilization & $\$ 435,000$ & $\$ 58,000$ \\
\hline Reduce FPF Electrical Power Costs & $\$ 10,500$ & $\$ 10,500$ \\
\hline Reduce New Fuel Processing Facility (FPF) S\&M & $\$ 13,100$ & $\$ 13,100$ \\
\hline Eliminate Unnecessary Waste Calcine Facility Work Orders & $\$ 0$ & $\$ 13,500$ \\
\hline Eliminate Rover As-builts & $\$ 0$ & $\$ 0$ \\
\hline PLANT OPERATIONS (Subtotal) & $\$ 210,400$ & $\$ 89,930$ \\
\hline Eliminate Step-off Shoe Covers & $\$ 12,000$ & $\$ 0$ \\
\hline Eliminate Dynamometer Usage & $\$ 4,700$ & $\$ 900$ \\
\hline Reduce Rigging/Crane Checks & $\$ 44,700$ & $\$ 14,200$ \\
\hline Reduce SO Testing Signatures & $\$ 24,600$ & $\$ 24,600$ \\
\hline Modify Load Testing Procedure & $\$ 12,900$ & $\$ 8,030$ \\
\hline Reduce Megger \& Continuity Testing & $\$ 37,500$ & 25,000 \\
\hline Downgrade Calibrations & $\$ 74,000$ & $\$ 17,200$ \\
\hline BALANCE OF PLANT (Subtotal) & $\$ 1,222,500$ & $\$ 598,292$ \\
\hline Streamline Utility Outage Approvals & $\$ 6,000$ & $\$ 3,000$ \\
\hline Streamline Fire Extinguisher Checks & $\$ 4,500$ & $\$ 3,000$ \\
\hline Improve PM Program & $\$ 51,500$ & $\$ 51,500$ \\
\hline Improve Office and Storage Facility Utilization & $\$ 224,000$ & $\$ 111,000$ \\
\hline Inactivate Surplus Facilities & $\$ 84,100$ & $\$ 84,170$ \\
\hline Conserve Electricity & $\$ 200,000$ & $\$ 200,000$ \\
\hline Eliminate Unnecessary Respirator Training & $\$ 88,300$ & $\$ 32,542$ \\
\hline Modify Freeze Protection Approach & $\$ 127,200$ & $\$ 95,080$ \\
\hline Eliminate Bulk Liquid Nitrogen & $\$ 44,400$ & $\$ 18,000$ \\
\hline Reduce Use of Plant Blue Coveralls & $\$ 392,500$ & $\$ 0$ \\
\hline
\end{tabular}


Table 3. Phase II recommendations and estimated cost savings

\begin{tabular}{|c|c|}
\hline Title & Annual Savings \\
\hline PHASE II & $\$ 12,785,800$ \\
\hline Implement Plant Work Control Process & $\$ 5,000,000$ \\
\hline Streamline Engineering Support & $\$ 5,000,000$ \\
\hline Streamline Waste Generation Forms & TBD \\
\hline Modify Document Change Review Process & $\$ 28,800$ \\
\hline Reduce Number of Special Procedures & $\$ 162,000$ \\
\hline Use Graded Approach to Safety Documentation & TBD \\
\hline Reduce Dosimetry Program & $\$ 42,000$ \\
\hline Apply Graded Approach to Double RadCon Tech Coverage & TBD \\
\hline Eliminate Unnecessary Security Certifications & $\$ 57,800$ \\
\hline Reduce QA Inspector Overtime & $\$ 234,000$ \\
\hline Eliminate Off-Normal Reports & $\$ 990,000$ \\
\hline Eliminate Truck Driver Change During Fuel Receipts & $\$ 63,300$ \\
\hline Assign Pre-Engineered Lifts to Operators & $\$ 83,300$ \\
\hline Reorganize SNF Department & $\$ 350,000$ \\
\hline Leave Rover Equipment in Cell $(\$ 3,300,000$ in FY-98 Only $)$ & $\$ 0$ \\
\hline Eliminate Unnecessary Bulk Chemical Analyses & $\$ 211,200$ \\
\hline Reduce Radiography Requirements & $\$ 50,000$ \\
\hline Reuse Contaminated Tools & $\$ 100,000$ \\
\hline Use Graded Approach to Contamination Survey Frequency & $\$ 32,300$ \\
\hline Use Grade Approach to CMTRs & TBD \\
\hline Improve Craft Training Scheduling & TBD \\
\hline Improve PM Program & TBD \\
\hline Eliminate Unnecessary Radiological Training & TBD \\
\hline Improve Training Plans & $\$ 282,100$ \\
\hline Allow Use of More Socket Welds & $\$ 99,000$ \\
\hline Eliminate 5 th Crew & TBD \\
\hline Eliminate High Temperature Feasibility Studies & TBD \\
\hline Reduce Criticality Alarm System & TBD \\
\hline Reduce Program Support Organizations & TBD \\
\hline
\end{tabular}




\section{CONCLUSION}

Cost effectiveness at ICPP is a major thrust in FY-96. Work packages were redlined earlier this fiscal year to develop activity baselines within the reduced budget allocation. This redlining effort included a substantial amount of cost savings. A budget review was then performed to ensure that ongoing activities had sufficient, but not excess, funding to meet activity milestones and deliverables. The budget review identified several million dollars for reallocation to below-the-line, high-priority activities. The Process Efficiency Improvement Activity was undertaken to increase productivity and thereby realize cost savings.

As a result of reviewing current work processes and procedures and identifying nonvalueadded steps for elimination, the first phase of the Process Efficiency Improvement Activity has identified $\$ 1.8 \mathrm{M}$ in FY -96 cost savings and more than $\$ 17 \mathrm{M}$ in estimated annual cost savings. Several of the identified process improvements can be completed in the near future with minimal implementation barriers. These near-term, Phase I, process improvements have been evaluated for estimated cost savings, with the savings adjusted based on improvement implementation costs and funds already expended to date. The approved Phase I recommendations and the associated implementation plans were submitted to the sponsors for endorsement and formed the basis for the change control packages submitted to the ICPP Change Control Board for approval and subsequent implementation.

Phase II of the Process Efficiency Improvement Activity will be started in the second quarter of FY-1996. An action plan will be developed for Phase II and will consist of three basic elements:

1. A "top-down" senior management review to eliminate unnecessary ICPP work scope and extend the impact of the Phase I recommendations.

2. Implementation of "longer term" recommendations identified in Phase I and extension of some recommendations to additional ICPP processes.

3. Identification of recommendations in areas not previously investigated. 
Appendix A

Phase I Recommendation Descriptions and Actions 


\begin{tabular}{|c|c|c|c|c|}
\hline No & Title & Description & Actions & Assignment \\
\hline 1 & Increase Use of Job Safety Analyses & $\begin{array}{l}\text { Expand the use of Job Safety Analysis (JSA), where } \\
\text { applicable, in lieu of Hazardous Work Permits (HWP). }\end{array}$ & $\begin{array}{l}\text { Delete WSOP WS-301, "Hazardous Work Permits", } \\
\text { and replace with a Management Control Procedure } \\
\text { identifying limited work situations when an HWP is } \\
\text { required. }\end{array}$ & Stuart \\
\hline 2 & Streamline Occurrence Reporting & $\begin{array}{l}\text { Implement DOE Order } 232.1 \text {, effective } 10-30-95 \text {, which } \\
\text { relaxed occurrence reporting criteria, resulting in an } \\
\text { estimated } 18 \% \text { fewer off-normal occurrences. }\end{array}$ & $\begin{array}{l}\text { Train authors and transmitters of occurrence reports } \\
\text { regarding the updated criteria. }\end{array}$ & Salcido \\
\hline 3 & Eliminate Test Results Review Team & $\begin{array}{l}\text { Eliminate the Test Results Review Team (TRRT), which } \\
\text { provides an independent review of Systems Operability } \\
\text { (SO) test results subsequent to Quality Assurance approval } \\
\text { of SO test results. }\end{array}$ & Modify WE- 23 procedure to eliminate the TRRT. & Salcido \\
\hline 4 & Streamline Review of Plant Changes & $\begin{array}{l}\text { TS 10E3.2 requires all physical changes to plant equipment } \\
\text { be approved by } 4 \text { departments and changes outside the } \\
\text { safety envelope be approved by DOE-ID prior to start of } \\
\text { installation, resulting in several layers of review and } \\
\text { approval. The process for screening and determination of } \\
\text { potential unreviewed safety questions (USQ) is performed } \\
\text { sparately. Proposal cancels TS } 10 \mathrm{E} 3.2 \text { and requires DOE- } \\
\text { ID approval only if the action is a USQ, in which case the } \\
\text { USQ process is used. }\end{array}$ & $\begin{array}{l}\text { Cancel TS 10E3.2, requires DOE approval. } \\
\text { Revise Engineering Practices Manual. } \\
\text { Revise WE-8. }\end{array}$ & Landon \\
\hline 5 & Improve Graded Approach of Quality Levels & $\begin{array}{l}\text { Change procedure WE-1, Quality Level and Safety Class } \\
\text { Item Designation, to implement LITCO procedure MCP- } \\
540 \text {, Assignment of Quality Levels. This will correlate the } \\
\text { quality level and rigor of review with the hazard category. } \\
\text { Since there are no hazard category I facilities at ICPP, } \\
\text { there will be no quality level I items. }\end{array}$ & $\begin{array}{l}\text { Revise WE-1. } \\
\text { Revise WE-8. } \\
\text { Revise Engineering Practices Manual. }\end{array}$ & $\begin{array}{l}\text { Valentine } \\
\text { Valentine } \\
\text { Landon }\end{array}$ \\
\hline 6 & Reduce Bioassay Samples & $\begin{array}{l}\text { Currently, nearly all Radiological II workers at ICPP are in } \\
\text { a bioassay program. Due to the mission change at ICPP, } \\
\text { this large number of samples does not represent the } \\
\text { potential for monitoring internal dose at the required level. } \\
\text { The number of samples could be reduced by } 75 \% \text {, taking } \\
\text { samples from a representative percentage of workers as } \\
\text { well as any worker who may be involved in circumstances } \\
\text { where a potential for } 100 \text { mrem internal dose exists. } \\
\end{array}$ & Change Technical Basis document. & Stuart \\
\hline 7 & Reduce RCTs Required for Moving Hot Dirt & $\begin{array}{l}\text { Five RCTs have been providing coverage to transport fill } \\
\text { dirt from "hot" dirt piles to the Tank Farm. Conditions have } \\
\text { changed and the remaining dirt is lower risk to transport, } \\
\text { allowing the use of only two RCTs to provide adequate } \\
\text { coverage. }\end{array}$ & Complete. & \\
\hline 8 & Reduce 603 Basin Water Sampling & $\begin{array}{l}\text { Although the CPP- } 603 \text { basin water chemistry is basically } \\
\text { stable, samples are taken once a week. Based on } \\
\text { chemistry stability, sampling once per quarter will meet the } \\
\text { needs of the facility for tracking PH, Chloride, Nitrate, and } \\
\text { gamma scan. }\end{array}$ & $\begin{array}{l}\text { Revise the TS sampling requirement, } \\
\text { Revise the sampling procedure. }\end{array}$ & Olson \\
\hline
\end{tabular}




\begin{tabular}{|c|c|c|c|c|}
\hline No & Title & Description & Actions & Assignment \\
\hline 9 & Reduce FAST Basin Water Monitoring & $\begin{array}{l}\text { Each week, two samples are pulled from each of six fuel } \\
\text { storage pools resulting in six individual samples and one } \\
\text { composite sample. Additionally, three samples are taken } \\
\text { in the recirculation loop. The samples are analyzed for } \\
\text { pH, conductivity, Chloride ion, gamma scan, and Strontium } \\
90 \text {. The composite sample can be eliminated. On-line } \mathrm{pH} \\
\text { and conductivity monitoring instrumentation can be } \\
\text { installed and the pH and conductivity sample analyses } \\
\text { eliminated. The Strontium } 90 \text { analysis can be performed } \\
\text { monthly instead of weekly. }\end{array}$ & $\begin{array}{l}\text { Install on-line } \mathrm{pH} \text { monitoring instrumentation. (in } \\
\text { progress to satisfy a UOR corrective action) } \\
\text { Install on-line conductivity instrumentation. (in } \\
\text { progress to satisfy a UOR corrective action) } \\
\text { Revise TS 5.6B5 to delete conductivity measurement } \\
\text { as Group I instrumentation. } \\
\text { Revise TP 4.5.3.36. }\end{array}$ & Olson \\
\hline 10 & Reduce FAST Stack Monitoring & $\begin{array}{l}\text { CPP-666 stack monitoring is operated as a Group I } \\
\text { instrument with monthly filter sampling and reporting. } \\
\text { Since FDP is shutdown, the montioring should be reduced } \\
\text { to Group III instrumentation with semiannual filter } \\
\text { sampling and reporting. The PM frequency should be } \\
\text { changed from monthly to quarterly and calibration should } \\
\text { be changed from monthly to annually. }\end{array}$ & $\begin{array}{l}\text { Modify TS 5.6B5. } \\
\text { Modify TS } 4.3 \mathrm{~B} 3 \text {. } \\
\text { Revise associated procedures. }\end{array}$ & Olson \\
\hline 11 & $\begin{array}{l}\text { Improve Process for Obtaining Radiological } \\
\text { Instrument Readings }\end{array}$ & $\begin{array}{l}\text { Currently, an RCT takes readings from RAM and CAM } \\
\text { instruments in several process areas at ICPP. These } \\
\text { readings can be taken by process operators during routine } \\
\text { process data readings and facility inspections and the data } \\
\text { provided to an RCT for any necessary analysis. }\end{array}$ & $\begin{array}{l}\text { Change MCP-93. } \\
\text { Revise associated guidance documents. }\end{array}$ & Stuart \\
\hline 12 & Modify RCT Utilization During Off-Shifts & $\begin{array}{l}\text { The mod-shift HP is upgraded to supervisor resulting in } \\
\text { less HP coverage, which often causes overtime and } \\
\text { elevates costs. Instead the mid-shift RCTS should report to } \\
\text { the area shift supervisor. }\end{array}$ & $\begin{array}{l}\text { Revise applicable procedures. } \\
\text { Issue policy letter. }\end{array}$ & Stuart \\
\hline 13 & Reduce Main Stack Monitoring & $\begin{array}{l}\text { The main stack is currently sampled on a daily basis. This } \\
\text { can be changed to monthly sampling and allow safe } \\
\text { operations. }\end{array}$ & $\begin{array}{l}\text { Change Environmental Monitoring Plan. } \\
\text { Modify associated procedures. }\end{array}$ & Stuart \\
\hline 14 & Reduce Tank Farm Monitoring & $\begin{array}{l}\text { RCRA characterization of waste solutions is conducted } \\
\text { annually on the tank farm. The characterization could be } \\
\text { eliminated for tanks in which conditions have not changed } \\
\text { since the last characterization. }\end{array}$ & Change the WAP and HLLWE Run Plan. & Sinclair \\
\hline 15 & Reduce Percolation Pond Checks & $\begin{array}{l}\text { Although the percolation ponds have been RCRA closed, } \\
\text { daily checks are made. The frequency of these checks } \\
\text { can be safely changed from daily to weekly. }\end{array}$ & $\begin{array}{l}\text { Modify associated procedures. } \\
\text { Modify data sheets. }\end{array}$ & Oswald \\
\hline 16 & Reduce Number of Sample Trip Blanks & $\begin{array}{l}\text { Currently, service waste trip blanks are collected once a } \\
\text { week. The collection of trip blanks can be reduced from } \\
\text { weekly to monthly. }\end{array}$ & Modify procedure. & $\begin{array}{l}\text { Oswald, } \\
\text { Olson }\end{array}$ \\
\hline 17 & Obtain WCR Readings Remotely & $\begin{array}{l}\text { RCRA surveillance checks are performed at WCF four } \\
\text { times per day, requiring operator entry. These checks can } \\
\text { be made once per week. Additionally, the instrumentation } \\
\text { can be moved to allow the readings to be taken remotely } \\
\text { from CPP- } 601 \text { or NWCF. }\end{array}$ & $\begin{array}{l}\text { Implement work order \#161818. (in progress) } \\
\text { Modify data sheets. }\end{array}$ & Oswald \\
\hline
\end{tabular}




\begin{tabular}{|c|c|c|c|c|}
\hline No & Title & Description & Actions & Assignment \\
\hline 18 & Reduce Deep Tank Monitoring & $\begin{array}{l}\text { The deep tank control room is entered once per shift for } \\
\text { sparge checks. Checking the alarms located in the CPP- } \\
601 \text { corridor is adequate. Additionally, RCRA checks are } \\
\text { performed once each day in the deep tank control room, } \\
\text { requiring Zone I protective clothing, although the area is } \\
\text { essentially radiologically clean. }\end{array}$ & Complete. & \\
\hline 19 & Reduce Bulk Chemical Readings & $\begin{array}{l}\text { Although NWCF is not operating, bulk chemical inventory } \\
\text { readings are taken once per day. While the NWCF is } \\
\text { down, these readings can be taken once per week. }\end{array}$ & Modify Bulk Chemical Inventory Sheet. & Oswald \\
\hline 20 & Reduce Fuel Charger Wrappings & $\begin{array}{l}\text { Three cask bags are required to wrap chargers prior to } \\
\text { transfer even though surveys show little or no } \\
\text { contamination on the cask following wash and wipe down. } \\
\text { Since the cask is considered clean, one cask bag will be } \\
\text { placed on the bottom of the cask and the charger placed in } \\
\text { the catch pan. }\end{array}$ & Modify procedure. & Olson \\
\hline 21 & Modify Cask Water Filling Procedure & $\begin{array}{l}\text { It takes approximately } 20 \text { minutes to fill the Peach Bottom } \\
\text { or NFS } 100 \text { cask, during which time no other work is } \\
\text { performed. The lid bolts can be safely loosened during the } \\
\text { first } 15 \text { minutes of the filling operation and the operators } \\
\text { can move away from the cask for the final } 5 \text { minutes in the } \\
\text { event there is any overflow. }\end{array}$ & Modify the procedure. & Olson \\
\hline 22 & Eliminate Unnecessary Cask Surveys & $\begin{array}{l}\text { Due to internal requirements, the NFS } 100 \text { cask is given an } \\
\text { incoming survey to meet } 49 \text { CFR shipping requirements and } \\
\text { is then given an extensive "grid" survey. No other cask is } \\
\text { required to have the same rigor when surveyed. The grid } \\
\text { survey requirement can be safely eliminated. }\end{array}$ & Complete. & \\
\hline 23 & Implement Lift Ring Stand & $\begin{array}{l}\text { Entries into a contamination area are required to attach the } \\
\text { CRNY-FS-950 to the } 903 \text { crane. The use of a stand to } \\
\text { position the lifting ring for attachment will reduce entries. }\end{array}$ & Complete modifications to the ring stand. & Olson \\
\hline 24 & Streamline Fuel Movement Plan Development & $\begin{array}{l}\text { Fuel Movement Plans (FMPs) are developed as the first } \\
\text { step in the process to transfer each phase of fuel from } \\
\text { CPP-603 to FAST. There is no specified format or content } \\
\text { requirements for the FMPs, resulting in increasingly } \\
\text { detailed plans. Content requirements should be } \\
\text { determined, as well as format requirements if necessary. }\end{array}$ & Document FMP content requirements. & Olson \\
\hline 25 & Improve HLW Operator Utilization & $\begin{array}{l}\text { Manpower is not being utilized efficiently in the Waste } \\
\text { Processing Operations Department. Many activities can } \\
\text { be performed by personnel with minimal cross-training. } \\
\text { The working groups within the department should be } \\
\text { combined to allow improved utilization. }\end{array}$ & Combine working groups within department. & Oswald \\
\hline 26 & Reduce FPF Electrical Power Costs & $\begin{array}{l}\text { Lighting at FPF is provided by construction light cords } \\
\text { powered by temporary load centers throughout the } \\
\text { building. Lights are left on } 24 \text { hours per day to facilitate } \\
\text { operator surveillance tours that were previously } \\
\text { performed once per day. A motion activated light can be } \\
\text { installed at the entrance and all lights operated at the } \\
\text { breakers. }\end{array}$ & $\begin{array}{l}\text { Install motion activated light. (in progress) } \\
\text { Identify and label breakers for lighting on load } \\
\text { centers. }\end{array}$ & Oswald \\
\hline
\end{tabular}




\begin{tabular}{|c|c|c|c|c|}
\hline No & Title & Description & Actions & Assignment \\
\hline 27 & Reduce FPF Surveillance and Maintenance & $\begin{array}{l}120 \text { emergency lights and } 33 \text { exit lights are located } \\
\text { throughout FPF, requiring maintenance, monthly checks, } \\
\text { and replacement of battery packs and bulbs. These lights } \\
\text { can all be disabled and flashlights can be used as back-up } \\
\text { power for entries. }\end{array}$ & $\begin{array}{l}\text { Remove battery packs, remove lights, and post exit } \\
\text { signs. } \\
\text { Modify procedure for surveillance to require } \\
\text { flashlights. } \\
\text { Cancel monthly checks and PMs. }\end{array}$ & Oswald \\
\hline 28 & Eliminate Unnecessary WCF Work Orders & $\begin{array}{l}\text { Although WCF is scheduled to be grouted, work orders are } \\
\text { in the system to correct safety concerns. The work orders } \\
\text { have been evaluated and risk-benefit evaluations } \\
\text { performed to determine which work orders could be } \\
\text { canceled. }\end{array}$ & Complete. & \\
\hline 29 & Eliminate Rover As-Builts & $\begin{array}{l}\text { Deactivation and equipment removal in Rover has } \\
\text { generated several work packages with ECRs that are } \\
\text { scheduled to be as-built. All as-building for Rover except } \\
\text { for utility and chemical lines have been placed on inactive } \\
\text { status. }\end{array}$ & Complete. & \\
\hline 30 & Eliminate Step-off Shoe Covers & $\begin{array}{l}\text { Personnel exit a contamination area in CPP- } 603 \text { to a posted } \\
\text { step off pad and, with shoe covers on, walk to a wurvey } \\
\text { station. Since step off pads are routinely surveyed and are } \\
\text { considered clean, the use of shoe covers to walk from a } \\
\text { clean area to a survey station is unnecessary. }\end{array}$ & Expand action beyon CPP- 603 . & Stuart \\
\hline 31 & Eliminate Dynomometer Usage & $\begin{array}{l}\text { As required by the hoisting and rigging manual, } \\
\text { dynomometers are presently required for FHU lifts in the } \\
\text { FAST facility. The dynomometers offer no protection } \\
\text { against hang up since the crane can not stop upward } \\
\text { movement quickly enough to prevent damage. A snubber } \\
\text { would be more appropriate. }\end{array}$ & $\begin{array}{l}\text { Determine risk of hang up. } \\
\text { Modify } 5519 X \text { forms. } \\
\text { Modify procedures. }\end{array}$ & Olson \\
\hline 32 & Reduce Rigging/Crane Checks & $\begin{array}{l}\text { Technical Standard 16B3 requires rigging/crane checks } \\
\text { prior to use each shift. Rigging checks can be performed } \\
\text { once per month and documented on form } 5519 \mathrm{X} \text { and } \\
\text { cranes checked once per day prior to first use each day. }\end{array}$ & $\begin{array}{l}\text { Deactivate TS } 15 B 3 . \\
\text { Modify WP- } 31 \text { and associated procedures to } \\
\text { discontinue use of } 5519 \mathrm{AX} \text { form. }\end{array}$ & $\begin{array}{l}\text { Hopla } \\
\text { Olson } \\
\text { Oswald }\end{array}$ \\
\hline 33 & Reduce SO Testing Signatures & $\begin{array}{l}\text { Currently, three people (engineering, quality, and } \\
\text { operations) sign off on SO tests. Using a graded approach, } \\
\text { two signatures should be sufficient. }\end{array}$ & Modify WE-19. & Grow \\
\hline 34 & Modify Load Testing Procedure & $\begin{array}{l}\text { The Hoisting and Rigging Manual requires } 10 \text { minutes hold } \\
\text { time for load testing, but does not address fuel buckets. } \\
\text { For fuel buckets the hold time can be safely reduces to } 1 \\
\text { minute since they are designed with a safety factor of } \\
\text { three. }\end{array}$ & $\begin{array}{l}\text { Define necessary testing. } \\
\text { Complete ECRs, WOCs, etc. to modify requirements. }\end{array}$ & Olson \\
\hline 35 & Reduce Meggar \& Continuity Testing & $\begin{array}{l}\text { Meggar and continuity testing is required on all new wire } \\
\text { installations and reterminations. This requirement can be } \\
\text { eliminated for low voltage ( } 600 \mathrm{~V}) \text { wire and loads less the } \\
100 \text { amps. A graded approach should be used for higher } \\
\text { voltage work. }\end{array}$ & $\begin{array}{l}\text { Revise guide specifications for service entrance } \\
\text { connections, high risk areas, and high voltage work. }\end{array}$ & Grow \\
\hline
\end{tabular}




\begin{tabular}{|c|c|c|c|c|}
\hline No & Title & Description & Actions & Assignment \\
\hline 36 & Downgrade Calibrations & $\begin{array}{l}\text { Military Standard MIL-STD- } 45662 \mathrm{~A} \text {, Calibrations Systems } \\
\text { Requirements, contains the requirements for establishing } \\
\text { and maintaining a calibration system for measuring and } \\
\text { test equipment (MT\&E). The standard has been } \\
\text { inappropriately applied to process instrument calibrations. } \\
\text { DOE Order } 5700.6 \mathrm{E} \text {, which specified the standard, has } \\
\text { been canceled. The standard should be applied to MT\&E } \\
\text { only. }\end{array}$ & $\begin{array}{l}\text { Revise MCP- } 2391 \text { to correctly apply standard. } \\
\text { Revise PRD. } \\
\text { Revise WE-3. } \\
\text { Revise worksheets. }\end{array}$ & Valentine \\
\hline 37 & Streamline Utility Outage Approvals & $\begin{array}{l}\text { Outage requests are generated each time utilities are } \\
\text { isolated for maintenance activities, requiring the } \\
\text { notification of five departments. Any changes in the } \\
\text { isolation valving or additional work instructions requires } \\
\text { notification of these departments even if the change does } \\
\text { not change the intent of the original outage. Of the } 16 \\
\text { H\&V systems that require outages, six should require } \\
\text { facility custodian notification only. }\end{array}$ & $\begin{array}{l}\text { Modify the following procedures: } \\
\text { 4.4.5.6, } \\
\text { 4.4.5.8, } \\
4.4 .5 .10 \text {, } \\
4.4 .5 .11 \text {, } \\
\text { 4.4.5.12, and } \\
\text { 4.4.5.36 }\end{array}$ & Chigbrow \\
\hline 38 & Streamline Fire Extinguisher Checks & $\begin{array}{l}\text { Utility Operations has a support technician check all fire } \\
\text { extinguishers throughout ICPP on a monthly basis to } \\
\text { comply with NFPA requirements. All facilities with an } \\
\text { active RCRA inspection program also perform monthly } \\
\text { checks of fire extinguishers in affected areas to comply } \\
\text { with RCRA requirements. The RCRA inspection } \\
\text { information is sufficient for NFPA requirements, negating } \\
\text { the need for Utility Operations checks of the affected } \\
\text { extinguishers. }\end{array}$ & $\begin{array}{l}\text { Issue required reading for RCRA inspectors to sign } \\
\text { off and punch the inspection card. }\end{array}$ & $\begin{array}{l}\text { Hopla, } \\
\text { Oswald, } \\
\text { Olson }\end{array}$ \\
\hline 39 & Improve PM Program & $\begin{array}{l}\text { The frequency of all PMs should be evaluated and the } \\
\text { intervals lengthened when possible. PMs should be } \\
\text { eliminated in instances where the PM cost exceeds the } \\
\text { replacement cost. Eliminate unnecessary PM in CPP- } 601 \\
\text { due to current operating level. }\end{array}$ & $\begin{array}{l}\text { Evaluate PMs to lengthen interval or eliminate where } \\
\text { feasible. }\end{array}$ & Hopla \\
\hline 40 & Improve Office and Storage Facility Utilization & $\begin{array}{l}\text { Not all office facilities are being utilized to the maximum } \\
\text { extent possible, including unnecessary use of leased } \\
\text { facilities, trailers, and temporary buildings. The use of } \\
\text { office space should be maximized and high cost lease } \\
\text { facilities should be eliminated where feasible. }\end{array}$ & Perform space utilization study for office areas. & Hopla \\
\hline 41 & Inactivate Surplus Facilities & $\begin{array}{l}\text { Several buildings not being used still have all utilities } \\
\text { available as well as freeze protection, surveillances, and } \\
\text { custodial services. }\end{array}$ & $\begin{array}{l}\text { Identify inactive buildings. } \\
\text { Isolate utilities and eliminate services for buildings. }\end{array}$ & Hopla \\
\hline 42 & Conserve Electricity & $\begin{array}{l}\text { Existing plant policy does not include an aggressive plan to } \\
\text { control and reduce electrical energy consumption. A } \\
\text { policy should be implemented to reduce consumption } \\
\text { including perimeter lighting, office lights, computer } \\
\text { systems, timers on water heaters, and thermostat settings. }\end{array}$ & Issue letter for energy conservation. & Hopla \\
\hline
\end{tabular}




\begin{tabular}{|c|c|c|c|c|}
\hline No & Title & Description & Actions & Assignment \\
\hline 43 & Eliminate Unnecessary Respirator Training & $\begin{array}{l}\text { Many personnel who maintain current respirator training } \\
\text { status seldom use a respirator. Many people have } \\
\text { maintained current status due to inability to complete } \\
\text { training quickly when required. Shoule only train those } \\
\text { individuals who have a need for the training. }\end{array}$ & Issue letter regarding respirator training. & $\begin{array}{l}\text { Murphy, } \\
\text { Oswald, } \\
\text { Olson }\end{array}$ \\
\hline 44 & Modify Freeze Protection Approach & $\begin{array}{l}\text { In accordance with the Freeze Protection Program, } \\
\text { operators record outside temperature every two hours } \\
\text { from September } 15 \text { through April } 15 \text { and perform facility } \\
\text { inspections as frequently as every two hours. A graded } \\
\text { approach should be implemented and procedures changed } \\
\text { to reflect the new WP-33 guidelines. Additionally, FPF } \\
\text { tours can be performed weekly rather than daily. }\end{array}$ & Modify procedures to allow graded approach. & $\begin{array}{l}\text { Hopla, } \\
\text { Oswald, } \\
\text { Olson }\end{array}$ \\
\hline 45 & Eliminate Bulk Liquid Nitrogen & $\begin{array}{l}\text { Bulk liquid nitrogen is stored in VES-WO-129 \& } 130 \text { and is } \\
\text { used to supply shielding window purges in FAST, back-up } \\
\text { air for the Service Waste Diversion System, and back-up } \\
\text { air for the APS exhaust blower dampers. Fast is in the } \\
\text { process of installing a different system for shielding } \\
\text { window purges and nitrogen bottles can be used for the } \\
\text { exhaust blower dampers. Bulk nitrogen is no longer } \\
\text { required. }\end{array}$ & $\begin{array}{l}\text { Modify CPP- } 605 \text { and } 666 . \\
\text { Modify associated procedures. } \\
\text { Cancel nitrogen deliveries. } \\
\text { Make separate arrangement for lab nitrogen. }\end{array}$ & $\begin{array}{l}\text { Olson } \\
\text { Oswald, } \\
\text { Olson } \\
\text { Oswald } \\
\text { Hunter }\end{array}$ \\
\hline 46 & Reduce Use of Plant Blue Coveralls & $\begin{array}{l}\text { Historically, the issuing of blue coveralls fulfilled a variety } \\
\text { of needs including the need for a layer of clothing beneath } \\
\text { the protective clothing required for working in } \\
\text { radiologically controlled areas. Modesty clothing/scrubs } \\
\text { have now taken the place of blues in this instance. Many } \\
\text { jobs and areas no longer require blues, although it has } \\
\text { become commonplace to wear them. Blues should only be } \\
\text { provided for chemical or "dirty" jobs. }\end{array}$ & $\begin{array}{l}\text { Develop policy regarding issuance of plant blue } \\
\text { coveralls. }\end{array}$ & Hopla \\
\hline
\end{tabular}


Appendix B

Recommendation Spreadsheet 


\begin{tabular}{|c|c|c|c|c|c|c|c|}
\hline \multicolumn{2}{|r|}{ No. Title } & \multirow[t]{2}{*}{ Annual Savings } & \multirow[t]{2}{*}{ FY-96 Savings } & \multirow[t]{2}{*}{ Work Package } & \multirow[t]{2}{*}{ Reduction } & \multirow[t]{2}{*}{ CCB Amount } & \multirow[t]{2}{*}{ Comments } \\
\hline & PAPEFWORKREVIEW REDUCTION & & & & & & \\
\hline 1 & 1 Increase Use of Job Safety Analyses & $\$ 135,000$ & $\$ 88.630$ & & & & \\
\hline 1 & I & & & 1.2 .3 .1 .1 .1 & $\$ 5,430$ & $\$ 5,430$ & \\
\hline 1 & it & & & $1.2 .3 .1 .1 .3 .2 . \mathrm{A}$ & $\$ 970$ & $\$ 970$ & \\
\hline 1 & it & & & 1.2 .3 .1 .1 .3 .2 .8 & $\$ 970$ & $\$ 970$ & \\
\hline 1 & 1. & & & $1.2 .3 .1 .1 .3 .2 . \mathrm{C}$ & $\$ 970$ & $\$ 970$ & \\
\hline 1 & 1 & & & 1.2 .3 .1 .1 .3 .2 .0 & $\$ 970$ & $\$ 970$ & \\
\hline 1 & & & & 1.2.3.1.1.3.2.E & $\$ 970$ & $\$ 970$ & \\
\hline 1 & & & & $1.2 .3 .1 .1 .3 .3 . \mathrm{A}$ & $\$ 970$ & $\$ 970$ & \\
\hline 1 & & & & 1.2.3.2.1.1.A & $\$ 7,100$ & $\$ 7,100$ & \\
\hline 1 & & & & 1.2.3.2.2.1.1.A & $\$ 7,100$ & $\$ 7,100$ & \\
\hline 1 & & & & $1.2 .3 .2 .2 .2 . \mathrm{B}$ & $\$ 2,360$ & $\$ 2,360$ & \\
\hline 1 & & & & 1.2.3.2.2.2.C & $\$ 2,360$ & $\$ 2,360$ & \\
\hline 1 & & & & 1.2.3.2.2.2.D & $\$ 2,360$ & $\$ 2,360$ & \\
\hline 1 & & & & 1.2.3.3.1.1.A & $\$ 9,350$ & $\$ 9,350$ & \\
\hline 1 & & & & $1.2 .3 .3 .1 .1 . \mathrm{C}$ & $\$ 9,350$ & $\$ 9,350$ & \\
\hline 1 & & & & $1.2 .3 .3 .1 .2 . \mathrm{A}$ & $\$ 13,900$ & $\$ 13,900$ & \\
\hline 1 & & & & 1.2.3.3.1.2.E & $\$ 2,400$ & $\$ 2,400$ & \\
\hline 1 & & & & 1.2.3.3.1.2.F & $\$ 2,400$ & $\$ 2,400$ & \\
\hline 1 & & & & 1.2.3.3.3.4.5.A & $\$ 18,700$ & $\$ 18,700$ & \\
\hline 2 & Streamline Occurrence Reporting & $\$ 541,800$ & $\$ 353,200$ & & & & \\
\hline 2 & & & & 1.2.3.1.1.3.1.A & $\$ 2,580$ & $\$ 2,580$ & \\
\hline 2 & & & & $1.2 .3 \cdot 1 \cdot 1.3 .1 .8$ & $\$ 2,580$ & $\$ 2,580$ & \\
\hline 2 & & & & $1.2 .3 .1 .1 .3 .1 . \mathrm{C}$ & $\$ 2.580$ & $\$ 2,580$ & \\
\hline 2 & & & & 1.2.3.1.1.3.1.D & $\$ 2,580$ & $\$ 2,580$ & \\
\hline 2 & & & & 1.2.3.1.1.3.2.A & $\$ 2,580$ & $\$ 2,580$ & \\
\hline 2 & & & & $1.2 .3 .1,1,3.2 . \mathrm{B}$ & $\$ 2,580$ & $\$ 2,580$ & \\
\hline 2 & & & & 1.2.3.1.1.3.2.C & $\$ 2,580$ & $\$ 2,580$ & \\
\hline 2 & & & & $1.2 .3 .1 .1 .3 .2 . \mathrm{D}$ & $\$ 2,580$ & $\$ 2,580$ & \\
\hline 2 & & & & $1.2 .3 \cdot 1 \cdot 1.3 .2 . \mathrm{E}$ & $\$ 2,580$ & $\$ 2,580$ & \\
\hline 2 & & & & $1.2 .3 .1,1,3.3, \mathrm{~A}$ & $\$ 2,580$ & $\$ 2,580$ & \\
\hline 2 & & & & 1.2 .3 .1 .7 .1 .4 .3 & $\$ 25,800$ & $\$ 25,800$ & \\
\hline 2 & & & & 1.2.3.1.8.1.A.B & $\$ 25,800$ & $\$ 25,800$ & \\
\hline 2 & & & & 1.2.3.2.1.1.A & $\$ 13,200$ & $\$ 13,200$ & \\
\hline 2 & & & & 1.2 .3 .2 .2 .2 .8 & $\$ 4,400$ & $\$ 4,400$ & \\
\hline 2 & & & & $1.2 .3 .2 .2 .2 . \mathrm{C}$ & $\$ 4,400$ & $\$ 4,400$ & \\
\hline 2 & $\cdot$ & & & 1.2 .3 .2 .2 .2 .0 & $\$ 4,400$ & $\$ 4,400$ & \\
\hline 2 & & & & $1.2 .3 .2 .6 .1 .4 . \mathrm{C}$ & $\$ 42,200$ & $\$ 42,200$ & \\
\hline 2 & & & & 1.2.3.3.1.1.A & $\$ 13,200$ & $\$ 13,200$ & \\
\hline 2 & & & & 1.2.3.3.1.1.B & $\$ 9,900$ & $\$ 9,900$ & \\
\hline 2 & & & & $1.2 .3 .3 .1 .1 . \mathrm{C}$ & $\$ 6,600$ & $\$ 6,600$ & \\
\hline 2 & & & & $1.2 .3 .3 .1 .2 . \mathrm{A}$ & $\$ 11,880$ & $\$ 11,880$ & \\
\hline 2 & & & & 1.2.3.3.1.2. & $\$ 2,970$ & $\$ 2,970$ & \\
\hline 2 & & & & 1.2.3.3.1.2.E & $\$ 5,940$ & $\$ 5,940$ & \\
\hline 2 & & & & 1.2 .3 .3 .1 .2 .5 & $\$ 5,940$ & $\$ 5,940$ & \\
\hline 2 & & & & $1.2 .3 .3 .1 .2 . G$ & $\$ 2,970$ & $\$ 2,970$ & \\
\hline 2 & & & & 1.2 .3 .3 .2 .3 & $\$ 37,500$ & \$o & Soft Savings \\
\hline 2 & & & & 1.2 .3 .3 .2 .4 & $\$ 37,500$ & so & Soft Savings \\
\hline 2 & & & & 1.2.3.3.3.3 & $\$ 72,800$ & so & Removed in Dec. rebaseline \\
\hline 3 & Eliminate Test Results Review Team & $\$ 36,000$ & $\$ 30,400$ & & & & \\
\hline 3 & & & & $1.2 .3 .1 .5 .1 .3 . \mathrm{A}$ & $\$ 7,800$ & \$o & Removed in Dec rebaseline \\
\hline 3 & & & & $1.2 .3 .1 .5 .2 .3 \mathrm{~A}$ & $\$ 7,800$ & $\$ 0$ & Removed in Dec rebaseline \\
\hline 3 & & & & 1.2 .3 .2 .2 .1 .2 .0 & $\$ 3,300$ & $\$ 3,300$ & \\
\hline 3 & & & & 1.2 .3 .2 .5 .1 .3 & $\$ 7,800$ & $\$ 0$ & Removed during wk pkg review \\
\hline 3 & & & & 1.2.3.2.6.1.1.A & $\$ 3,700$ & $\$ 3,700$ & \\
\hline 4. & Streamline Review of Plant Changes & $\$ 75,800$ & $\$ 40,300$ & & & & \\
\hline 4 & & & & 1.2 .3 .1 .1 .1 & $\$ 14,700$ & $\$ 14,700$ & \\
\hline 4 & & & & $1.2 .3 .1 .1 .3 .1 . \mathrm{A}$ & $\$ 830$ & $\$ 830$ & \\
\hline 4 & & & & 1.2.3.1.1.3.1.B & $\$ 830$ & $\$ 830$ & \\
\hline 4 & & & & $1.2 .3 .1 .1 .3 .1 . \mathrm{C}$ & $\$ 830$ & $\$ 830$ & \\
\hline 4 & & & & $1.2 .3 .1 .1 .3 .1 . \mathrm{D}$ & $\$ 830$ & $\$ 830$ & \\
\hline 4 & & & & $1.2 .3 .1 .1 .3 .2 . \mathrm{A}$ & $\$ 1,650$ & $\$ 1,650$ & \\
\hline 4 & & & & $1.2 .3 .1 .1 .3 .2 . \mathrm{B}$ & $\$ 1,650$ & $\$ 1,650$ & \\
\hline 4 & & & & 1.2.3.1.1.3.2.C & $\$ 1,650$ & $\$ 1,650$ & \\
\hline 4 & & & & $1.2 .3 .1 .1 .3 .2 . \mathrm{D}$ & $\$ 1,650$ & $\$ 1,650$ & \\
\hline 4 & & & & 1.2.3.1.1.3.2.E & $\$ 1.650$ & $\$ 1,650$ & \\
\hline 4 & & & & 1.2.3.1.1.3.2.G & $\$ 1,650$ & $\$ 1,650$ & \\
\hline 4 & & & & $1.2 .3 .1 .1 .3 .3 . \mathrm{A}$ & $\$ 1,650$ & $\$ 1,650$ & \\
\hline 4 & & & & $1.2 .3 .1 .1 .3, \mathrm{~A}$ & $\$ 1,650$ & $\$ 1,650$ & \\
\hline 4 & & & & 1.2.3.2.1.1.A & $\$ 2,300$ & $\$ 2,300$ & \\
\hline 4 & & & & $1.2 .3 .2 .2 .1 .1 . \mathrm{A}$ & $\$ 4,500$ & $\$ 4,500$ & \\
\hline 4 & & & & 1.2.3.2.2.2.B & $\$ 760$ & $\$ 760$ & \\
\hline 4 & & & & 1.2.3.2.2.2.C & $\$ 760$ & $\$ 760$ & \\
\hline 4 & & & & 1.2 .3 .2 .2 .2 .0 & $\$ 760$ & $\$ 760$ & \\
\hline
\end{tabular}




\begin{tabular}{|c|c|c|c|c|c|c|c|}
\hline No. 1 & Titlo & Annual Savings & FY-96 Savings & Work Package & Reduction & CCB Amount & Comments \\
\hline 5 & Improve Graded Approach of Quality Levels & $\$ 48,500$ & $\$ 30,680$ & & & & \\
\hline 5 & & & & 1.2.3.1.1.1 & $\$ 12,600$ & $\$ 12,600$ & \\
\hline 5 & & & & 1.2.3.1.1.3.2.A & $\$ 1,510$ & $\$ 1,510$ & \\
\hline 5 & & & & 1.2 .3 .1 .1 .3 .2 .8 & $\$ 1,510$ & $\$ 1,510$ & \\
\hline 5 & & & & 1.2.3.1.1.3.2.C & $\$ 1,510$ & $\$ 1,510$ & \\
\hline 5 & & & & $1.2 .3 .1 \cdot 1 \cdot 3.2 . \mathrm{D}$ & $\$ 1,510$ & $\$ 1,510$ & \\
\hline $5 !$ & & & & 1.2.3.1.1.3.2.E & $\$ 1,510$ & $\$ 1,510$ & \\
\hline 5 & & & & 1.2.3.1.1.3.2.9 & $\$ 1,510$ & $\$ 1,510$ & \\
\hline 5 & & & & 1.2.3.1.1.3.3.A & $\$ 1,510$ & $\$ 1,510$ & \\
\hline 5 & & & & 1.2.3.1.1.3.A & $\$ 1,510$ & $\$ 1,510$ & \\
\hline 5 & & & & 1.2.3.2.1.1.A & $\$ 1,500$ & $\$ 1,500$ & \\
\hline 5 & & & & 1.2.3.2.2.1.1.A & $\$ 3,000$ & $\$ 3,000$ & \\
\hline 5 & & & & 1.2.3.2.2.2.B & $\$ 500$ & $\$ 500$ & \\
\hline 5 & & & & 1.2.3.2.2.2.C & $\$ 500$ & $\$ 500$ & \\
\hline \multirow{4}{*}{5.} & & & & 1.2.3.2.2.2.D & $\$ 500$ & $\$ 500$ & \\
\hline & Subtotal & $\$ 837,100$ & $\$ 543,210$ & & $\$ 543,210$ & $\$ 372,010$ & \\
\hline & & & & & & & \\
\hline & \multicolumn{7}{|l|}{ MONITOFING } \\
\hline 6 & Feduce Bioassay Sampies & $\$ 375,000$ & $\$ 200,000$ & & & & \\
\hline 6 & & & & 1.2 .3 .3 .3 .2 & $\$ 200,000$ & $\$ 0$ & Removed during wk pkg review \\
\hline 7 & Reduce ACTs Required for Moving Hot Dirt & $\$ 0$ & $\$ 27,600$ & & & & \\
\hline 7 & & & & 1.2.3.2.5.4.1 & $\$ 27,600$ & $\$ 27,600$ & \\
\hline 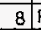 & Reduce 603 Basin Water Sampling & $\$ 233,300$ & $\$ 115,000$ & & & & \\
\hline 8 & & & & $1.2 .3 .1 .1 .1 .4 . \mathrm{A}$ & $\$ 115,000$ & $\$ 115,000$ & \\
\hline 9 & Reduce FAST Basin Water Monitoring & $\$ 103,600$ & $\$ 57,100$ & & & & \\
\hline 9 & & & & $1.2 .3 .1 .1 .3 .1 . \mathrm{C}$ & $\$ 57,100$ & $\$ 57,100$ & \\
\hline 10 & Reduce FAST Stack Monitoring & $\$ 29,600$ & $\$ 29,500$ & & & & \\
\hline 10 & & & & 1.2.3.1.1.3.1 & $\$ 29,600$ & $\$ 0$. & Removed in rebaseline \\
\hline 11 & $\begin{array}{l}\text { Improve Process for Obtaining Radiological } \\
\text { Instrument Readings }\end{array}$ & $\$ 0$ & $\$ 0$ & & & $\$ 0$ & Denied by RadCon \\
\hline 121 & Modify RCT Utilization During Off-Shifts & $\$ 75,000$ & so & & & $\$ 0$ & No FY96 savings \\
\hline 13 & Reduce Main Stack Monitoring & $\$ 147,300$ & So & & & $\$ 0$ & Req. negotiation w/ State \\
\hline 141 & Reduce Tank Farm Monitoring & $\$ 99,000$ & $\$ 0$ & & & So & Add'l charact. req'd by State \\
\hline 15 & Reduce Percolation Pond Checks & $\$ 14,400$ & $\$ 8,600$ & & & & \\
\hline 15 & & & & 1.2.3.2.2.2.D & $\$ 8,600$ & $\$ 8,600$ & \\
\hline 16 & Reduce Number of Sample Trip Blanks & $\$ 1,600$ & $\$ 1,100$ & & & & \\
\hline 16 & & & & 1.2 .3 .2 .2 .2 .0 & $\$ 1,100$ & $\$ 1,100$ & \\
\hline 17 & Obtain WCF Readings Remolely & $\$ 36,900$ & $\$ 23,900$ & & & & \\
\hline 17 & & & & $1.2 .1 .3 .2 . B$ & $\$ 23,900$ & $\$ 23,900$ & \\
\hline 18 & Reduce Deep Tank Moniloring & $\$ 19,800$ & $\$ 14,900$ & & & & \\
\hline 18 & & & & 1.2.1.3.2.B & $\$ 14,900$ & $\$ 14,900$ & \\
\hline $19 \mathrm{f}$ & Reduce Bulk Chemical Readings & $\$ 0$ & $\$ 7,900$ & & & & \\
\hline \multirow{4}{*}{9} & & & & $1.2 .3 .2 .2 .1 .1 . \mathrm{A}$ & $\$ 7,900$ & $\$ 7,900$ & \\
\hline & Subtotal & $\$ 1,135,500$ & $\$ 485,700$ & & $\$ 485,700$ & $\$ 256,100$ & \\
\hline & & & & & & & \\
\hline & \multicolumn{7}{|l|}{ SPENT FUEL OPERATIONS } \\
\hline 201 & Reduce Fuel Charger Wrappings & $\$ 529,600$ & $\$ 10,000$ & & & & \\
\hline 20 & & & & 1.2 .3 .1 .1 .1 .2 .2 .8 & $\$ 1,400$ & $\$ 1,400$ & \\
\hline 20 & & & & 1.2.3.1.1.1.2.5.2.8 & $\$ 3,400$ & $\$ 3,400$ & \\
\hline 20 & & & & $1.2 .3 .1 .1 .1 .3 .1 .4 . B$ & $\$ 5,200$ & $\$ 5,200$ & \\
\hline 211 & Modify Cask Water Filling Procedure & $\$ 0$ & $\$ 0$ & & & $\$ 0$ & Denied by RadCon \\
\hline $22 \cdot$ & Eliminate Unnecessary Cask Surveys & $\$ 35,000$ & $\$ 35,000$ & & & & \\
\hline 22 & & & & 1.2.3.1.1.3.2.C & $\$ 17,500$ & $\$ 17,500$ & \\
\hline 22. & & & & 1.2.3.1.1.3.2.D & $\$ 17,500$ & $\$ 17,500$ & \\
\hline 231 & Implement Lift Ring Stand & $\$ 1,200$ & $\$ 400$ & & & & \\
\hline 23 & & & & 1.2.3.1.1.3.2.C & $\$ 200$ & $\$ 200$ & \\
\hline 23 & & & & 1.2 .3 .1 .1 .3 .2 .0 & $\$ 200$ & $\$ 200$ & \\
\hline 24 & Streaminne Fuel Movement Plan Development & $\$ 5,000$ & $\$ 5,000$ & & & & \\
\hline \multirow[t]{4}{*}{24} & & & & 1.2.3.1.1.1.3.4.A & $\$ 5,000$ & $\$ 5,000$ & \\
\hline & Subtotal & $\$ 570,800$ & $\$ 50,400$ & & $\$ 50,400$ & $\$ 50,400$ & \\
\hline & & & & & & & \\
\hline & HIGH LEVEL WASTE OPERATIONS & & & & & & \\
\hline 25 & Improve HLW Operator Utilization & $\$ 435,000$ & $\$ 58,000$ & & & & \\
\hline 25 & & & & 1.2.1.3.2.A & $\$ 29,000$ & $\$ 29,000$ & \\
\hline 25 & & & & 1.2.1.3.2. & $\$ 29,000$ & $\$ 29,000$ & \\
\hline 26 & Feduce FPF Electrical Power Costs & $\$ 10,500$ & $\$ 10,500$ & & & & \\
\hline 26 & & & & 1.2 .1 .3 .2 .8 & $\$ 10,500$ & $\$ 10,500$ & \\
\hline 27 & Reduce FPF Surveillance and Maintenance & $\$ 13,100$ & $\$ 13,100$ & & & & \\
\hline 27 & & & & $1.2 .1 \cdot 3.2 .8$ & $\$ 13,100$ & $\$ 13,100$ & \\
\hline 28 & Eliminate Unnecessary WCF Work Orders & $\$ 0$ & $\$ 13,500$ & & & & \\
\hline 28 & & & & 1.2 .1 .3 .2 .8 & $\$ 13,500$ & $\$ 13,500$ & \\
\hline 29 & Eliminate Rover As-builts & $\$ 0$ & $\$ 0$ & & & $\$ 0$ & Not funded in FY96 \\
\hline & Subtotal & $\$ 458,600$ & $\$ 95,100$ & & $\$ 95,100$ & $\$ 95,100$ & \\
\hline & & & & & & & \\
\hline
\end{tabular}




\begin{tabular}{|c|c|c|c|c|c|c|c|}
\hline \multicolumn{2}{|r|}{ No.|Title } & \multirow[t]{2}{*}{ Annual Savings } & \multirow[t]{2}{*}{ FY-96 Savings } & \multirow[t]{2}{*}{ Work Package } & \multirow[t]{2}{*}{ Reduction } & \multirow[t]{2}{*}{ Cc8 Amount } & \multirow[t]{2}{*}{ Comments } \\
\hline & GENERAL OPERATIONS & & & & & & \\
\hline 30 & Eliminate Step-off Shoe Covers & $\$ 12,000$ & so & & & & \\
\hline 31 & Eliminate Dynomometer Usage & $\$ 4,700$ & $\$ 900$ & & & & \\
\hline 31 & & & & 1.2.3.1.1.3.2.A & $\$ 900$ & $\$ 900$ & \\
\hline 32 & Reduce Rigging/Crane Checks & $\$ 44,700$ & $\$ 14,200$ & & & & \\
\hline 32 & & & & 1.2 .3 .1 .1 .1 & $\$ 9,690$ & $\$ 9,690$ & \\
\hline 32 & & & & 1.2.3.1.1.3.2.B & $\$ 1,130$ & $\$ 1,130$ & \\
\hline 32 & & & & $1.2 .3 .1 .1 .3 .2 . \mathrm{C}$ & $\$ 1,130$ & $\$ 1,130$ & \\
\hline 32 & & & & $1.2 .3 .1 .1 .3 .2 . \mathrm{D}$ & $\$ 1,130$ & $\$ 1,130$ & \\
\hline 32 & & & & $1.2 .3 .1,1.3 .2 . \mathrm{E}$ & $\$ 560$ & $\$ 560$ & \\
\hline 32 & & & & $1.2 .3 \cdot 1 \cdot 1.3 . \mathrm{A}$ & $\$ 560$ & $\$ 560$ & \\
\hline 33 & Reduce SO Testing Signatures & $\$ 24,600$ & $\$ 24,600$ & & & & \\
\hline 33 & & & & 1.2.3.1.5.1.3.A & $\$ 8,200$ & $\$ 0$ & Removed in Dec rebaseline \\
\hline 33 & & & & 1.2.3.1.5.2.3.A & $\$ 8,200$ & $\$ 0$ & Removed in Dec rebaseline \\
\hline 33 & & & & 1.2 .3 .2 .5 .1 .3 & $\$ 8,200$ & \$o & Removed during wk pkg review \\
\hline 34 & Modify Load Testing Procedure & $\$ 12,900$ & $\$ 8,030$ & & & & \\
\hline 34 & & & & 1.2 .3 .1 .1 .1 & $\$ 2,930$ & $\$ 2,930$ & \\
\hline 34 & & & & 1.2 .3 .1 .1 .3 .2 .8 & $\$ 850$ & $\$ 850$ & \\
\hline 34 & & & & 1.2.3.1.1.3.2.D & $\$ 850$ & $\$ 850$ & \\
\hline 34 & & & & $1.2 \cdot 3 \cdot 1 \cdot 1 \cdot 3 \cdot 3 . \mathrm{A}$ & $\$ 3,400$ & $\$ 3,400$ & \\
\hline 35 & Feduce Megger \& Continuity Testing & $\$ 37,500$ & $\$ 25,000$ & & & & \\
\hline 35 & & & & EA 64890 & $\$ 8,400$ & $\$ 0$ & Removed during wk pkg review \\
\hline 35 & & & & EA 99427 & $\$ 8,300$ & $\$ 0$ & Removed during wk pkg review \\
\hline 35 & & & & EA 99452 & $\$ 8,300$ & $\$ 0$ & Removed during wk pkg review \\
\hline 36 & Downgrade Calibrations & $\$ 74,000$ & $\$ 17,200$ & & & & \\
\hline 36 & & & & 1.2.1.3.2.B & $\$ 5,700$ & $\$ 5,700$ & \\
\hline 36 & & & & 1.2.3.1.1.3.1.D & $\$ 2,900$ & $\$ 2,900$ & \\
\hline 36 & & & & $1.2 .3 .2 .2 .1 .1 . \mathrm{A}$ & $\$ 5,700$ & $\$ 5,700$ & \\
\hline \multirow{4}{*}{36} & & & & 1.2.3.3.1.2.A & $\$ 2,900$ & $\$ 2,900$ & \\
\hline & Subtotal & $\$ 210,400$ & $\$ 89,930$ & & $\$ 89,930$ & $\$ 40,330$ & \\
\hline & & & & & & & \\
\hline & BALANCE OF PLANT & & & & & & \\
\hline 37 & Strearmine Utility Outage Approvals & $\$ 6,000$ & $\$ 3,000$ & & & & \\
\hline 37 & & & & 1.2.3.3.1.2.F & $\$ 3,000$ & $\$ 3,000$ & \\
\hline 38 & Streamline Fire Extinguisher Checks & $\$ 4,500$ & $\$ 3,000$ & & & & \\
\hline 38 & & & & $1.2 .3 .3 .1 .2 . \mathrm{G}$ & $\$ 3,000$ & $\$ 3,000$ & \\
\hline 391 & Improve PM Program & $\$ 51,500$ & $\$ 51,500$ & & & & \\
\hline 39 & & & & $1.2 \cdot 1.3 .2 . \mathrm{B}$ & $\$ 1,500$ & $\$ 1,500$ & \\
\hline 39 & & & & 1.2.3.3.1.2.D & $\$ 33,340$ & $\$ 33,340$ & \\
\hline 39 & & & & 1.2.3.3.1.2.E & $\$ 16.660$ & $\$ 16,660$ & \\
\hline 401 & Improve Office and Storage Facility Unilization & $\$ 224,000$ & $\$ 111,000$ & & & & \\
\hline 40 & & & & 043100000 & $\$ 20,000$ & $\$ 0$ & \\
\hline 40 & & & & 043200000 & $\$ 8,000$ & $\$ 0$ & \\
\hline 40 & & & & 043300000 & $\$ 75,000$ & $\$ 0$ & \\
\hline 40 & & & & 043400000 & $\$ 8,000$ & $\$ 0$ & \\
\hline 411 & Inactivate Surplus Facilities & $\$ 84,100$ & $\$ 84,170$ & & & & \\
\hline $41 !$ & & & & $1.2 .3 .3 .1 .3 . \mathrm{G}$ & $\$ 11,700$ & $\$ 11,700$ & \\
\hline 41 & & & & 1.2.3.3.1.3.E & $\$ 72,470$ & $\$ 72,470$ & \\
\hline 42 & Conserve Electricity & $\$ 200,000$ & $\$ 200 ; 000$ & & & & \\
\hline 42 & & & & 1.2 .3 .3 .1 .3 .1 & $\$ 200,000$ & $\$ 200,000$ & \\
\hline 438 & Eliminate Unnecessary Respirator Training & $\$ 88,300$ & $\$ 32.542$ & & & & \\
\hline 43 & & & & $1.2 .1 .3 .2 . \mathrm{B}$ & $\$ 5,300$ & $\$ 5,300$ & \\
\hline 43 & & & & 1.2.3.2.1.1.A & $\$ 5,300$ & $\$ 5,300$ & \\
\hline 43 & & & & 1.2 .3 .2 .2 .2 .8 & $\$ 1,760$ & $\$ 1,760$ & \\
\hline 43 & & & & 1.2.3.2.2.2.C & $\$ 1,760$ & $\$ 1,760$ & \\
\hline 43 & & & & 1.2.3.2.2.2.D & $\$ 1,760$ & $\$ 1,760$ & \\
\hline 43 & & & & 1.2.3.3.3.1.A & $\$ 16.662$ & $\$ 16,662$ & \\
\hline $44 \sqrt{1}$ & Modify Freeze Protection Approach & $\$ 127,200$ & $\$ 95,080$ & & & & \\
\hline 44. & & & & $1.2 \cdot 1 \cdot 3.2 . \mathrm{B}$ & $\$ 19,300$ & $\$ 19,300$ & \\
\hline 44 & & & & 1.2.3.1.1.3.1.A.B & $\$ 5,200$ & $\$ 5,200$ & \\
\hline 44 & & & & $1.2 .3 .2 .1 .1 . \mathrm{A}$ & $\$ 8,400$ & $\$ 8,400$ & \\
\hline 44 & & & & 1.2.3.2.2.1.1.A & $\$ 3,900$ & $\$ 3,900$ & \\
\hline 44 & & & & $1.2 .3 .2 .2 .2 . \mathrm{B}$ & $\$ 2,760$ & $\$ 2,760$ & \\
\hline 44 & & & & $1.2 .3 .2 .2 .2 . \mathrm{C}$ & $\$ 2,760$ & $\$ 2,760$ & \\
\hline 44 & & & & 1.2.3.2.2.2.D & $\$ 2,760$ & $\$ 2.760$ & \\
\hline 44 & & & & 1.2.3.3.1.1.A & $\$ 25,000$ & $\$ 25,000$ & \\
\hline 44 & & & & $1.2 .3 .3 .1 .2 . \mathrm{J}$ & $\$ 25,000$ & $\$ 25,000$ & \\
\hline 45 & Eliminate Bulk Liquid Nitrogen & $\$ 44,400$ & $\$ 18,000$ & & & & \\
\hline 45 & & & & $1.2 .3 .2 .2 .2 . \mathrm{C}$ & $\$ 9,000$ & $\$ 9.000$ & \\
\hline 45 & & & & $1.2 .3 .2 .2 .2 . \mathrm{D}$ & $\$ 9,000$ & $\$ 9,000$ & \\
\hline 46 & Reduce Use of Plant Blue Coverails & $\$ 392,500$ & $\$ 0$ & & & & \\
\hline & Subtotal & $\$ 1,222,500$ & $\$ 598,292$ & & $\$ 598,292$ & $\$ 487,292$ & . \\
\hline & TOTAL & & 91862632 & & $\$ 1,862,632$ & $\$ 1,301,232$ & \\
\hline
\end{tabular}

